\title{
Climate Change and Internet of Things Technologies- Sustainable Premises of Extending the Culture of the Amurg Cultivar in Transylvania-A Use Case for Târnave Vineyard
}

\author{
Veronica Sanda Chedea ${ }^{1, * \mathbb{C}}$, Ana-Maria Drăgulinescu ${ }^{2,3} \mathbb{1}$, Liliana Lucia Tomoiagă ${ }^{1}$, Cristina Bălăceanu ${ }^{2}$ \\ and Maria Lucia Iliescu ${ }^{1}$ (D) \\ 1 Research Station for Viticulture and Enology Blaj (SCDVV Blaj), 515400 Blaj, Romania; \\ tomoiagaliliana@yahoo.com (L.L.T.); marina_iliescu@yahoo.com (M.L.I.) \\ 2 Research and Development Department, Beia Consult International, 007182 Bucharest, Romania; \\ ana.dragulinescu@upb.ro (A.-M.D.); cristina.balaceanu@beia.ro (C.B.) \\ 3 Telecommunications Department, University Politehnica of Bucharest, 061071 Bucharest, Romania \\ * Correspondence: chedeaveronica@yahoo.com
}

check for updates

Citation: Chedea, V.S.; Drăgulinescu, A.-M.; Tomoiagă L.L.; Bălăceanu, C.; Iliescu, M.L. Climate Change and Internet of Things

Technologies-Sustainable Premises of Extending the Culture of the Amurg Cultivar in Transylvania-A Use Case for Târnave Vineyard. Sustainability 2021, 13, 8170. https://doi.org/10.3390/ su13158170

Academic Editor: José Manuel Mirás-Avalos

Received: 2 June 2021

Accepted: 16 July 2021

Published: 21 July 2021

Publisher's Note: MDPI stays neutral with regard to jurisdictional claims in published maps and institutional affiliations.

Copyright: (c) 2021 by the authors. Licensee MDPI, Basel, Switzerland. This article is an open access article distributed under the terms and conditions of the Creative Commons Attribution (CC BY) license (https:// creativecommons.org/licenses/by/ $4.0 /)$.

\begin{abstract}
Known for its dry and semi-dry white wine, the Târnave vineyard located in central Transylvania is challenged by the current climate change, which has resulted in an increase of the period of active vegetation by approximately 15-20 days, the average annual temperature by $1-1.5^{\circ} \mathrm{C}$ and also the amount of useful temperatures (useful thermal balance for the grapevine). Furthermore, the frost periods have been reduced. Transylvania is an important Romanian region for grapevine cultivation. In this context, one can use the climatic changes to expand their wine assortment by cultivating an autochthonous grapevine variety called Amurg. Amurg is a red grape cultivar homologated at SCDVV Blaj, which also homologated 7 cultivars and 11 clones. Because viticulture depends on the stability of meteorological and hydrological parameters of the growing area, its foundations are challenged by climate change. Grapevine production is a long time investment, taking at least five years before the freshly planted vines produce the desired quality berries. We propose the implementation of a climate change-based precision viticulture turn-key solution for environmental monitoring in the Târnave vineyard. This solution aims to evaluate the grapevine's micro-climate to extend the sustainable cultivation of the Amurg red grapes cultivar in Transylvania with the final goal of obtaining Protected Designation of Origin (PDO) rosé and red wines from this region. Worldwide, the changing conditions from the existing climate (a 30-year average), used in the past hundred years to dictate local standards, such as new and erratic trends of temperature and humidity regimes, late spring freezes, early fall frosts, storms, heatwaves, droughts, area wildfires, and insect infestations, would create dynamic problems for all farmers to thrive. These conditions will make it challenging to predict shifts in each of the components of seasonal weather conditions. Our proposed system also aims to give a solution that can be adapted to other vineyards as well.
\end{abstract}

Keywords: climate change; Amurg cultivar; Internet of Things; precision viticulture

\section{Introduction}

The evolving overall wine-growing environment represents three facets of the wine world: production, distribution, and wine consumption [1]. The first element of the wine's evolving environment is its biological and chemical origins [1]. The evolving geography of winemaking refers to the dynamics of localization and distribution of viticulture and enology practices for the last ten millennia [1-3]. Besides the well-known grapevine growing zones, commercial viticulture is currently also found in the tropics, in higher altitude areas such as Hawaii, Mexico, Brazil, Bolivia, and Peru [4]. To produce enough sugars for fermentation to yield alcohol, the genus Vitis L. (grapevine) requires cycles of colder temperatures (and high diurnal temperature fluctuations) for grapes maturation 
and ripening [1,5]. Today, the wine industry is full of creativity and change, as new grapevine cultivars are created to expand the limits of wine production beyond its known boundaries $[1,6]$. The diversification (or rediscovery) of autochthonous grown grapevine cultivars and the consequent global acceleration of wine consumption rates have been balancing the increase of worldwide wine production starting in the 1970s $[1,7,8]$. This growth in the wine industry has also been enabled by globalization, for better or worse $[8,9]$.

The importance and demand of viticulture and wine industry products are given by their place of origin, plant cultivars, design, and taste, which is undoubtedly different than every other agricultural outcome worldwide [10]. The characteristics of the grape harvest and, by consequence, of the wine production are mostly dictated by the features of the climate and soil in which particular grape cultivars are produced [11]. The growing season affects the qualities of the harvested grapes, whereas the fermentation stage and the bottling period affect the wine that is crafted from them [12]. Terroir is the most often used (and abused) term in the wine vocabulary and is now a touchstone for the promotion of fine wine $[13,14]$.

Terroir is a term with French origins that means for a wine produced from grapes grown in a specific region, under certain circumstances, its fragrance will have particular aromas, tastes, appearances, and textures; in summary, it is characterized by a site fingerprints [10-12,14-16]. In this way, terroir develops a specific character for a particular cultivar of grapes planted in a specific area over a particular growth period. Therefore, the physical environment is most important topographically, geologically, and pedologically $[10,12]$.

Thus, the physical environment includes the slope, the soil composition, the depth, the parent materials, mineral quality, texture, humidity content, and the water retention, astronomical, climate, and weather aspects (sun angles and emplacement during the growing period, dawn-day visibility, humidity range and timing, rain, temperature, heating grades, cooling at night, wind speed and direction, the environmental elements that contribute to the seasonal pattern in the atmosphere, timing and intensity of severe weather, such as hail, freezing, and snowfall) during the most biologically active seasons for grapevine $[10,17]$. In addition, the biological factors of a vineyard environment-biodiversity of flora and fauna that will increase the good microorganisms and predators of insects, thus lowering the risks of grapevine's pests and diseases-are the natural components of terroir $[10,17]$. While a competent winemaker may claim that good wine is produced irrespective of the geographic location (appellation or denomination) of grape production, modern grapevine growers (usually) agree that "location matters" [18].

Each wine producer (and seller) argues that their wine is exceptional, rather than run-of-the-mill, identifying their product not only based on wine's standardized, extrinsic characteristics [19-21]. The inherent properties of a specific wine and the contrast with other related wines are the deciding factors in their value $[1,22,23]$. The winemakers use the terroir to adapt the grapevine varietal characteristics to the particular vineyard environment to produce a unique wine [24]. They pair their work with the time and place to deliver a certain vintage wine, a fact that reflects that unique location during a single year in which very certain atmospheric and hydrogeophysical conditions were encountered [25]. By consequence, no other wine was or is ever going to be exactly like that specific vintage because the weather is different every wine season [26-28]. Patterns change throughout the year, adverse weather may or may not occur, as with other variables from year to year, and the timestamp for all events that influence growth and production of the vineyards are continuously changing during an annual or growing season $[7,29]$. At the end of the distribution chain, the advertiser invites or even urges the customer to choose the wine produced by a specific vintner from a specific time and place because of its unique characteristics $[1,27,30]$.

Climate change is undermining the fundamentals of viticulture and, consequently, of winemaking because grapevine growing depends on local weather and hydrological conditions being stable $[7,31]$. Changes in each seasonal weather factor are often difficult 
to forecast [32-34]. Cultivated grapes reflect a long-term effort in which it takes at least five years to achieve their optimal production and quality [35]. In the context of climate change, grapes have been considered as the "canary on the coal mine" because this global phenomenon, recognized and studied for almost 40 years, influences wine quality through its impact on viticulture [36]. Some impacts can be expected, some not so [37,38]. Changes from the environmental record (a 30-year average) that has been used to dictate local standards for the past century will produce dynamic problems requiring all farmers to face up to new and erratic regimes of temperature and humidity, late spring freezes, early fall frosts, flooding, heatwaves, droughts, area wildfires, and pest attacks [35]. Increasing climatic instability in a given area would raise the risks related to extremes in climate conditions, which in turn would reduce the economic feasibility of winemaking [39]. In addition, practicing viticulture at higher altitudes and latitudes may lead to more environmental interventions and ecological change and imbalance [40].

Precision agriculture, together with data analytics, has the potential to reshape the entire viticulture environment, from cultivation to the wine market and its interactions with other ecosystems.

Precision agriculture technologies and equipment are a combination of Geographic Positioning Systems (GPS) and Geographic Information Systems (GIS) for geo-mapping, automatics steering systems, acquisition units, and sensing devices, which can be mounted on farm machines or fields [41] to work in an unattended manner, variable rate technologies and communication modules [42,43]. Moreover, UAVs (Unmanned Aerial Vehicles) can overtake agricultural tasks as image acquisition, spraying [43], crop damage identification, weed detection [44], and infestation mapping [45]. Increasing UAVs tasks, though, determine higher power consumption and, consequently, might render the precision agriculture systems less sustainable or viable [46].

Climate-Smart Agriculture (CSA) [47] is a concept that encourages the adoption of smart agriculture practices for water and nutrient management, the cultivation of stressresistant crops, precision fertigation, green manures, and UAVs, thus rendering precision agriculture as an instrument to decrease the environmental impact [48].

The current paper presents a particularization of the CSA concept for vineyards and viticulture, Climate Change-based Precision Viticulture (CCPV). This concept enriches the previously defined CSA by adopting sustainable low-environmental impact viticultural procedures and practices. CCPV further improves these technologies through the exploitation of the current climate modifications and Internet of Things technologies.

Consequently, the objectives of the paper are:

- To present the existing types of viticulture practices and to highlight the added value that precision viticulture brings to the current practices,

- To present the background of the Romanian and, more specifically, Transylvanian viticulture and the impact of the climatic changes in Transylvanian viticulture,

- To reveal the impact of the Internet of Things solutions in viticulture,

- To present the Amurg grapevine cultivar, as a cultivar whose cultivation can be extended based on the climatic changes context and IoT technologies,

- To introduce the Climatic Change Precision Viticulture (CCPV) concept to benefit from climatic changes, decision support systems, and IoT technologies to support the extension of the Amurg cultivar and to increase the sustainability of viticulture, by lowering the energetic inputs: fertilizers, herbicides, fungicides, insecticides, and gas,

- To propose a sustainable CCPV architecture for a smoother adaption of the Amurg cultivar to Transylvania climate conditions, increased grapevine productivity and income, and lowered costs in terms of the resources used,

- To reveal the improvements brought by the proposed Internet of Things technologies in viticulture.

The paper is organized as follows: In Section 2, the classification of the main viticulture practices is presented. Section 3 shows the most recent precision viticulture (PV) systems employing IoT technologies as implemented in practice and improving the farming activity. 
As Romania is an essential viticultural region, in Section 4, the general context of grapevine cultivation in this area is presented. In addition, in Section 5, we singularize Târnave, a significant Romanian viticultural region. Section 6 offers the background for the culture in Târnave vineyards of Amurg - a disease tolerant autochthonous grapevine cultivar for POD red and rosé wines. In Section 7, the morphological, agrobiological, and technological characteristics of the grapevine Amurg cultivar are presented. Section 8 depicts Amurg's diseases tolerance and resistance. Section 9 introduces the Climate Change-based Precision Viticulture, proposes and describes the CCPV architecture and its components. Finally, Section 10 concludes the paper, highlights the future directions, and emphasizes the open challenges.

\section{Types of Viticulture}

Depending on the methods and on the technological operations, six types of viticulture can be currently distinguished (Figure 1) [49].

\section{Conventional viticulture}

Integrated viticulture

Organic viticulture

Ecologic viticulture

Bio-dynamic viticulture

Precision viticulture

Figure 1. Categories of viticulture.

Further, we briefly review each type of viticulture. Nevertheless, for a more comprehensive approach, which is not the subject of this paper, they should be analyzed from five perspectives: (1) practices, (2) soil chemical composition or modifications, (3) impact on grape quality, (4) production, (5) economy (Figure 2).

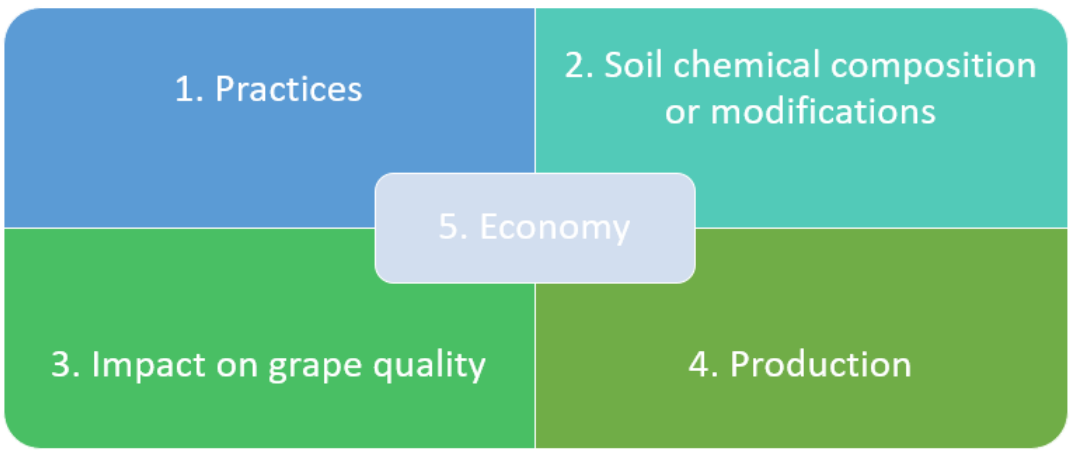

Figure 2. Perspectives for viticulture type descriptions. 


\subsection{Conventional Viticulture}

Conventional viticulture supposes the control of the crop using synthetic pesticides, mineral fertigation, and herbicides [50]. Due to the application of fungicides and fertilizers, the soil can be severely afflicted in terms of helpful bacteria and fungi. Moreover, the application of fertilizers has a significant impact on soil acidity [51]. Furthermore, the crops may learn resistance to the pesticides, requiring an increase of the doses applied.

\subsection{Integrated Viticulture}

Integrated viticulture combines biological techniques and cultivation procedures [52], aiming at reducing chemical usage. It may be considered more environmentally friendly than conventional viticulture [53]. Maykish et al. mention that integrated viticulture is not regulated by any certification [53]. Still, Integrated Pest Management (IPM) programs assess the adoption of sustainable practices as crop rotation, prevention of harmful organisms spreading, use of sustainable physical, biological, and adoption of other non-chemical methods. A complete list of integrated pest management practices for Europe may be found in [54]. In what concerns the certification programs, we mention, for example, in the USA, LIVE (Low Input Viticulture and Enology), SIP (Sustainability in Practice) [55] or Certified California Sustainable Wine (CCSW) programs, and in Europe, respectively, International Organization for Biological and Integrated Control (IOBC) [56].

\subsection{Organic Viticulture}

Organic viticulture represents a type of viticulture where instead of mineral fertilization, organic fertilization is performed employing approved non-synthetic substances. The same applies to pesticides or herbicides application. In addition, the use of genetically modified products is not authorized [57]. Organic farming uses copper and sulfur [52,58] as fungicides, but often, the soil copper allowed can be exceeded [59]. From the chemical point of view, due to the lack of mineral fertilization, nitrogen levels tend to be very low [60]. Green manure treatment, though, revealed to increase inorganic nitrogen, the concentration determined by Zanzotti et al. [61] being higher for soil samples where green manure developed than in the case of the samples acquired from the soil to which mineral fertilization was applied.

In 2018, 8.7\% of the total viticultural zones were organically cultivated [52]. Organic viticulture is regulated according to the regulations specific to the region. For Europe, one must follow the guidelines of the Regulation of the European Commission (EC) no. 203, published in 2012.

In a study [62] involving three wineries in Cyprus, the authors compared the wine production generated by the wineries based on the crop management methods used by the vineyard growers. Each of the wineries adopted a different technique as follows: the first one (W1) represented conventional viticulture, where high quantities of synthetic fertilizers and pesticides were used; the second one (W2) followed organic viticultural techniques, while the third one (W3) used only a small quantity of synthetic fertilizers without synthetic pesticides. Table 1 compares the production of the three wineries.

Table 1. Comparison between the wine production generated by different crop management methods in vineyards found in Limassol, Cyprus [62].

\begin{tabular}{ccccc}
\hline Winery & Practices & Surface [ha] & $\begin{array}{c}\text { Production } \\
\text { (0.75 L Bottles) }\end{array}$ & $\begin{array}{c}\text { Production Increase with } \\
\text { Respect to Conventional } \\
\text { Viticulture (\%) }\end{array}$ \\
\hline W1 & Conventional viticulture & 2.5 & 40,000 & - \\
\hline W2 & Organic viticulture & 5 & 80,000 & 11.5 \\
\hline W3 & $\begin{array}{c}\text { Only small quantities of } \\
\text { synthetic fertilizers; no } \\
\text { synthetic pesticides }\end{array}$ & 6.5 & 120,000 & 0 \\
\hline
\end{tabular}




\subsection{Ecological Viticulture}

According to [63], elements belonging to the so-called "ecological compensation area", e.g., isolated trees, groves, etc., are positively correlated to the biodiversity of the ecosystem specific to vineyards. Compared to conventional viticulture, ecological viticulture practices make use only of ecological-certified agricultural products, thus obtaining yields without synthetic chemicals or artificial pesticides and fertilizers [64].

\subsection{Bio-Dynamic Viticulture}

Biodynamic viticulture is based on an anthroposophical philosophy [52], where the vineyard is considered as a living organism, part of the soil and influenced by the soil and all its changes [49]. Biodynamic viticulture follows the same regulations as organic viticulture [65].

There were studies on Sangiovese biodynamic viticulture where a significantly lower predawn water potential $\left(\psi_{p d}\right)$ was observed in the biodynamic plots [66]. A lower stomatal conductance was observed. In addition, the biodynamic plots revealed a significant increase in the enzymatic activity of grapevine leaves. The latter may be because, in particular, the quartz powder-based horn silica preparation used in this study might determine the plant resistance by upregulating the plant defense mechanisms. Further, this again might influence the berry composition under biodynamic management [65].

The most important difference between the organic and biodynamic systems resides in the fact that, in biodynamic systems, specific biodynamic preparations are applied [67]. These preparations are meant to stimulate the cycling of soil nutrients to promote the photosynthetic activity of the crops and the compost transformation [68].

According to [69], biodynamic farming, in general, and biodynamic viticulture, in particular, can increase microbial diversity. Setati et al. [69] performed an experiment in which they compared three South African adjacent vineyards from the point of view of the microbiome, that is, the bacterial communities [70]. The three vineyards followed the cultivation practices in Table 2 .

Table 2. Comparison between conventional, integrated and biodynamic viticulture in [69].

\begin{tabular}{ccccc}
\hline Vineyard & Practices & $\begin{array}{c}\text { Species Diversity (Shanon's } \\
\text { Diversity Index) }\end{array}$ & $\begin{array}{c}\text { Species Evenness } \\
\text { (Pielou's Index) }\end{array}$ & $\begin{array}{c}\text { Species Richness } \\
\text { (Menhinick Index) }\end{array}$ \\
\hline V1 & Conventional viticulture & 1.2 & 0.5 & 0.96 \\
\hline V2 & Integrated viticulture & 1.45 & 0.63 & 1.06 \\
\hline V3 & Biodynamic viticulture & 2.15 & 0.76 & 1.45 \\
\hline
\end{tabular}

The authors determined the biodiversity indices (Menhinick, Pielou, and Shannon's Diversity indices). From the values of these indices, they have shown that biodynamic viticulture has the highest biodiversity, followed by integrated and conventional viticulture.

\subsection{Precision Viticulture}

Precision viticulture outperforms conventional practices [71] with decision support systems based on data automatically acquired from sensor networks [72]. Precision viticulture enables farmers to perform site-specific crop management. Based on data collected from crops, one can optimize the management of inputs for maximizing returns while minimizing inputs.

Using a so-called Decision Support System (DSS), the farm manager will be able to determine accurate spray timing (fertilizers or pesticides), avoiding over or under application [73]. Based on disease models, one can perform protective irrigation based on timely frost warnings and determine harvesting dates based on growing degree days. Nevertheless, such site-specific action requires accurate and site-specific data, delivered 
in near-real-time to the farmer's desk. DSS is not an automated decision-making tool-it helps the manager to make better decisions.

The paper introduces a new type of precision agriculture: Climate Change-based Precision Agriculture, but not before presenting the general context of viticulture in Romania and describing the last 30-years' changes and achievements in the viticultural sector.

\section{Precision Viticulture: Impact and IoT Solutions}

To propose better solutions for viticulture, one must have a good knowledge of the existing solutions and the current background of viticulture, with an emphasis on the particularities of the region in which one will implement the solutions. This section presents several precision viticulture (PV) systems based on IoT that have been proposed recently. The designs aim to improve farming practices, together with more straightforward and more efficient work in a vineyard.

Our most recent work [74] aimed to assess the relevance and the benefits of using the Smart Agriculture Xtreme platform from Libelium [75] in Romanian vineyards. The vineyard monitoring system follows another approach, which is built upon a layered Internet of Things architecture. In this way, the architecture brings the advantage of being scalable, in comparison with other proposed systems [49,76-78]. Moreover, the paper revealed that key parameters such as soil oxygen concentration, soil dielectric permittivity, soil, and air temperature and humidity could be monitored in real-time, with benefits in assessing the quality of the soil, and thus, the status of the vineyard. For example, the values obtained in the experimental results in [74] were compared with reference values of soil quality parameters as found in the literature [79].

Pérez-Expósito et al. [49] proposed an IoT PV system for easier remote monitoring of vineyards. The system includes both hardware and software parts. A WSN was developed, obtaining extensive real-time data from the field, such as the vine state at a specific moment, the weather parameters, and different statistics, etc. Alerts are being generated concerning various measures that need to be taken (e.g., for pest and disease prevention and detection, for multiple changes of the climate, etc.). A web-based interface displays the collected data. The system is a low-cost one and can work in different climates, in regions with different soil types, and with various conformations. First, it was implemented in Spain (Galicia), with two different ESP8266-based node types, one that collects information about the atmosphere and the other one of the soil. To reduce the consumption of energy, one used IP66 boxes for the encapsulation of the two-node types. Finally, from ecological considerations, the system was also provided with a solar power subsystem.

In [71], a real-time acquisition and monitoring PV system was proposed, having the advantages of low consumption of energy, a low cost of the hardware implementation and the IoT devices, as well as a straightforward process of monitoring the temperature and moisture of the soil and transmitting this information to a base station. The system can also alert at the occurrence of a disease or pest of the plants in the vineyard when a drone is sent to the specific area and takes pictures that are processed afterward when the drone returns to the base station.

Maraš et al. [76] developed and implemented a PV system in Podgorica (Montenegro), a 2.300 ha region with a Mediterranean climate that also presents influence from the surrounding mountains suitable for vineyards (with approximately 11.5 million grapevines). Twenty varieties of grapes were included in the study at 20 different sites, where soil moisture was monitored through LoRa devices, collaborating with the company DunavNET. Each device was provided with a solar panel to be independent energetically. The placement of soil moisture sensors was done both at 25 and $50 \mathrm{~cm}$ depth in the soil. Such a system can help wine producers to analyze, control, and make decisions according to the data they receive towards the goal of an optimized production that also considers any environmental problems that might take place in the vineyard.

In [78], the SEnviro system was proposed, which is an IoT-based architecture for vineyard monitoring. The system also enables disease prediction, thus leading to an 
increase in the wine quality and a reduction of the grape losses in the vineyard. The system was implemented in Spain (province Castelló). It consisted of two parts: a node of sensors (SEnviro node) and an IoT software platform capable of managing different sensor nodes (SEnviro connect). Four SEnviro nodes were deployed and installed in the vineyards, and a fifth node was used for tests in a location nearby the laboratory. The collaboration between the SEnviro node and SEnviro connect in the vineyard monitoring enables an autonomous operation and the possibility to send alerts when a disease or another problem is detected in the vineyard.

Vous et al. [80] implemented the architecture of a PV system based on IoT that optimizes the production of wine. The cultivation and harvest conditions were also considered in the attempt to increase the efficiency of such a system. The proposal also enables the quick, accurate and efficient choice of biotypes and new types of soil for the vineyard; moreover, it improves the production quality by considering the vineyard's response to different meteorological and soil characteristics. As compared to other approaches, the system can monitor both soil and atmospheric conditions before harvest. The system was implemented in the western part of Greece, which also includes three important islands (Corfu, Zakynthos, and Kefalonia).

In [81], the authors proposed an approach to implement IoT in PV by using the middleware EXEHDA. Thus, in the monitored vineyards, context awareness was provided for the devices at the analyzed site. Fog computing was used towards achieving this purpose.

Giordano and Verrastro [82] analyzed the IoF2020 project (Internet of Food and Farm 2020), with Big Wine Optimization as a use case that included wine production systems both conventional (in France) and organic (in Italy). The project included real-time weather monitoring, optimized water use during the production of wine, and improved data acquisition and management from many vineyards, together with enhanced quality and quantity of the produced wine. The study also considered that, because of the global warming phenomenon, previously not-suited areas for vineyards can nowadays be used for viticulture. By implementing IoT technologies, the environment can also be better preserved because of reduced use of electricity, water, and carbon and lower quantities of waste.

Suciu et al. [83] presented a case study of measurements in a 100 ha vineyard located in Romania (Cogeleac, in the county of Constanța) that produces Cabernet Sauvignon wine. The results were obtained by using an IoT-based system that included sensors for measuring the relative humidity and temperature of the air, the wetness degree of leaves, the direction and speed of the wind, the quantity of rain, together with solar panels and pyranometers. The study is an extension of a previous one [84], which implemented, at the same site, Cloud IoT and Big Data methods for predicting the diseases and providing alerts in PV applications. The proposed implementation used an M2M remote telemetry station.

In [85], the authors evaluated in an experimental setting in a vineyard in Spain the benefits of using IoT technologies that integrate a wireless sensor network (WSN), unmanned aerial vehicles (UAVs), and an engine for the processing and visualization of data. This system can help wine producers to access quickly, with a friendly interface, the data that WSN and UAVs collect from the vineyard.

Table 3 presents an overview of some of the smart viticulture systems used $[49,74,76,77,86]$. 
Table 3. Overview of the results obtained through the use of smart viticulture systems, adapted from [74].

\begin{tabular}{|c|c|c|c|c|c|}
\hline & \multicolumn{5}{|c|}{ References } \\
\hline Feature & [74] & [76] & [77] & [49] & [86] \\
\hline Sensors & $\begin{array}{c}\text { RHT, SM, ST, SH, } \\
\text { SR, AP, WD, LH, } \\
\text { NL, RFL, UVR }\end{array}$ & SM & RHT, ST, RFL & RHT, SM, ST & $\begin{array}{c}\text { RHT, WD, ST, RFL, } \\
\text { AP }\end{array}$ \\
\hline $\begin{array}{l}\text { Hardware } \\
\text { platform }\end{array}$ & $\begin{array}{c}\text { Libelium } \\
\text { SmartAgriculture } \\
\text { Xtreme }\end{array}$ & $\mathrm{NaN}$ & $\mathrm{NaN}$ & ESP8266 & LinkIt ONE \\
\hline $\begin{array}{c}\text { Other monitoring } \\
\text { devices }\end{array}$ & Drones & No & No & Weather station & No \\
\hline Other data & Satellite images & No & Ontology Data & No & No \\
\hline Alerting & Yes & Recipe & Yes & Yes & Yes \\
\hline Analysis & Yes & Yes & No & Yes & Yes \\
\hline Dashboard & DISAVIT & AgroNET & Not mentioned & Yes & No \\
\hline Target Actions & $\begin{array}{c}\text { Disease prevention, } \\
\text { yield, nutrients } \\
\text { level estimation, } \\
\text { irrigation, } \\
\text { fertigation, } \\
\text { planning }\end{array}$ & Irrigation & $\begin{array}{l}\text { Disease detection, } \\
\text { send alerts, } \\
\text { recommendations, } \\
\text { farmer's feedback }\end{array}$ & $\begin{array}{c}\text { Downy mildew, } \\
\text { prevention }\end{array}$ & $\begin{array}{c}\text { prevention, disease } \\
\text { detection }\end{array}$ \\
\hline Effective results & $\begin{array}{l}\text { aerated soil, RH } \\
\text { 5-month mean } \\
\text { value of } \mathrm{RH}: \\
54.24 \% \text {, in the } \\
\text { optimum range } \\
\text { (55-65\%) for grape } \\
\text { development }\end{array}$ & $\begin{array}{l}\text { reducing of water } \\
\text { loss by precision } \\
\text { irrigation, } \\
\text { adaptation to } \\
\text { cultivars' different } \\
\text { water needs, } \\
\text { reduced } \\
\text { manpower }\end{array}$ & $\begin{array}{l}\text { early detection of } \\
\text { eventual pests and } \\
\text { diseases attack } \\
\text { risks, precise } \\
\text { grapevine } \\
\text { phenophases } \\
\text { indication }\end{array}$ & $\begin{array}{l}\text { monitoring } \\
\text { grapevine status, } \\
\text { platform-based } \\
\text { grapevine growers } \\
\text { alerting, minimize } \\
\text { farm's energy } \\
\text { consumption }\end{array}$ & $\begin{array}{l}\text { Alert the growers } \\
\text { for Downy mildew, } \\
\text { Powdery mildew, } \\
\text { Black rot, Botrytis } \\
\text { prevention in the } \\
\text { function of } \\
\text { detected soil and } \\
\text { air temperature, } \\
\text { soil and air } \\
\text { humidity, } \\
\text { atmospheric } \\
\text { pressure, rainfall, } \\
\text { wind direction, } \\
\text { and speed }\end{array}$ \\
\hline
\end{tabular}

$\mathrm{RHT}=$ relative humidity and temperature, $\mathrm{SM}=$ soil moisture, $\mathrm{ST}=$ soil temperature, $\mathrm{SH}=$ soil humidity, $\mathrm{SR}=$ solar radiation, $\mathrm{AP}=$ atmospheric pressure, $\mathrm{WD}=$ wind, $\mathrm{RFL}=$ rainfall, $\mathrm{LH}=$ leaf humidity, $\mathrm{NL}=$ nutrient level, $\mathrm{UVR}=$ ultraviolet radiation.

\section{Viticulture in Romania-General Context}

According to the FAO's statistics, in 2019, Romania ranked 10th in the world out of 98 countries for the grapevine cultivated area and harvested 176.340 ha and 18 th out of 98 countries concerning the production of the grapes with 973,990 tonnes [87]. The total tonnage of wine produced in Romania in 2018 was 125,743 tonnes, ranking Romania 18th globally [88]. Moreover, the OIV (Organisation Internationale Vitivinicole) statistics [89] in 2020 revealed that Romania kept its position in the grapevine cultivated area ranking with a surface of 190.000 ha. On the other hand, OIV places Romania in 13th place globally from the point of view of wine production with 3.6 million hectolitres. Romania is located between $43^{\circ} 37^{\prime}-48^{\circ} 15^{\prime} \mathrm{N}$ lat and $20^{\circ} 15^{\prime}-29^{\circ} 44^{\prime} \mathrm{E}$ long, in Eastern Europe, having a temperate continental climate, Dfb and Dfa in a Koppen-Geiger climate updated classification $[90,91]$. The annual average temperature is $8{ }^{\circ} \mathrm{C}$ at the northern limit, to $11{ }^{\circ} \mathrm{C}$ at the southern boundary, and up to $11.7^{\circ} \mathrm{C}$ in the plains [91,92]. The climate is influenced from the east by the steppe climate, from the south-west by the Mediterranean climate, and from the west and north-west oceanic climate [91]. The topography is diverse and distinct and comprises $28 \%$ mountains, in the middle of the country, $42 \%$ plateaus and 
hills, and 30\% plain land [91]. More than half of Romania, more precisely $62 \%$, is covered by arable land [93], with viticulture mainly concentrated in hilly and plateau areas [91]. Due to the adequate climate for grape production, in Romania, grapevine growing is a traditional practice that has arisen and developed throughout history [91,94]. Eight large grapevine growing regions (Figure 3) with specific environmental conditions, as a result of their proximity to the Carpathian mountains (altitude: $2500 \mathrm{~m}$ ), the Danube river, and the Black Sea, constitute the nationwide viticultural area [91,94]. Furthermore, these regions include 141 plantations or vineyards, the southernmost of these is situated at $43^{\circ} \mathrm{N}$, and the northernmost at $48^{\circ} \mathrm{N}$ [91]. The wine production types are differentiated from south to north depending on the accumulation of heliothermic resources, due to the wide latitude of the Romanian land, as it follows: the southern limit $\left(43^{\circ} \mathrm{N}\right)$ is suitable for the table grape production [95], the southern half of Romania (between $43^{\circ} \mathrm{N}$ and $45^{\circ} \mathrm{N}$ ) is predominantly characterized by red wine production, in the northern half of the country (between $43^{\circ} \mathrm{N}$ and $\left.45^{\circ} \mathrm{N}\right)$, the white wine production is predominant, and at the northern limit $\left(48^{\circ} \mathrm{N}\right)$, white table wine and sparkling wine production prevails [91]. Figure 3 presents the eight important viticultural zones (VZ) of Romania, which are: Transylvanian Plateau (VZ 1), Moldavian Hills (VZ 2), Muntenia and Oltenia Hills (VZ 3), Banat Hills (VZ 4), Crișana and Maramureș Hills (VZ 5), Dobrogea Hills (VZ 6), Danube Terraces (VZ 7), sands and other suitable terrains from the South (VZ 8) [91,94].

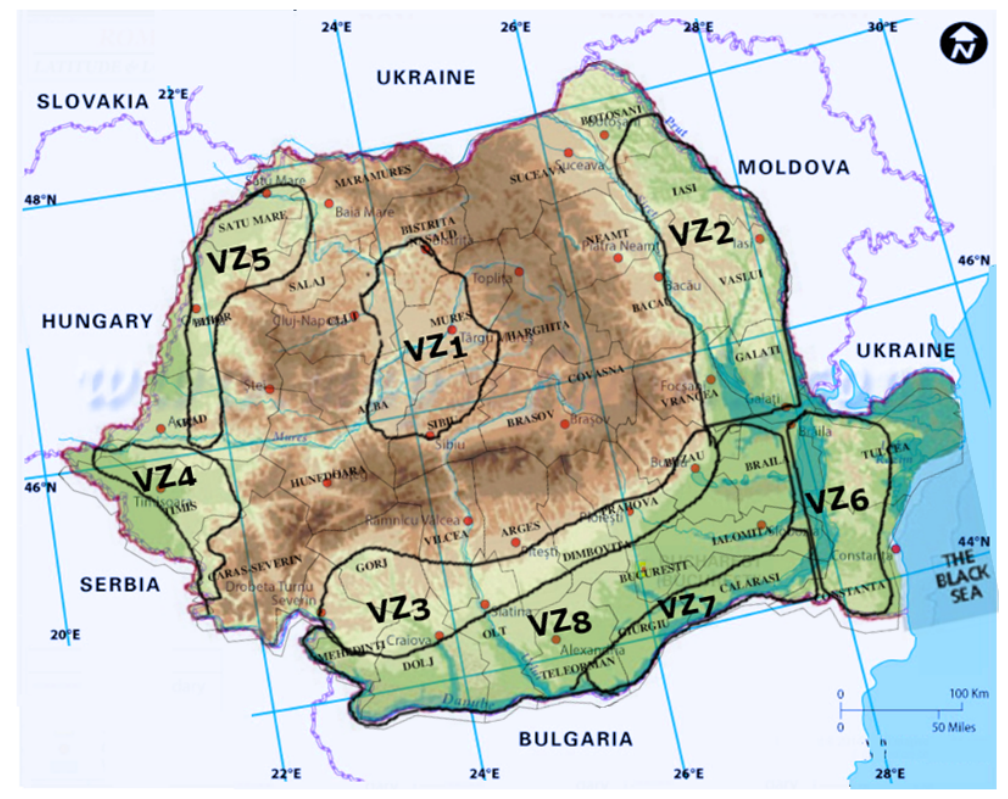

Figure 3. Viticultural zones in Romania.

The map of the Romanian vineyards presented in Figure 3 was compiled using GIMP editor and four maps: (1) Romania's relief map, (2) Romania's administrative map, (3) the map extracted from the Corine Land Cover Data-base 2006 Europe of the European Environment Agency (EEA 2006) [91] and the Romanian map from Maps of World [96]. Each Romanian viticultural zone, in addition to the popular international grapevine cultivars, have Vitis vinifera cultivars that are autochthonous tolerant and resistant to pests $[97,98]$ and weather extremes and offer the local wine production specificity [91]. The specific characteristics of the Romanian vineyards are integrated within the grapevine growing technology adapted to the local cultivars cultivated in these areas $[91,97,99]$.

VZ1 is suitable for obtaining quality and table white wines (QWW and TWW) that are dry, semi-dry and sweet from the cultivars such as Fetească albă, Pinot gris, Traminer roz, Sauvignon, Riesling Italian, Muscat Ottonel, as well as for sparkling white wines (SWW) from the cultivars Fetească regală, Fetească albă, Riesling Italian.

In the VZ2 of the Moldovian Hills, there is a cultivated grapevine for semi-sweet and sweet QWW and TWW from the cultivars Grasă de Cotnari, Fetească albă, Francusa, 
Tamaioasa romaneasca, Muscat Ottonel, Fetească regală, Aligote, Muscat Ottonel, Zghihara de Husi, Riesling Italian, Galbenă de Odobești, Plavaie, for quality and table red wines (QRW and TRW) from the cultivars Fetească neagră, Pinot noir, Băbească neagră, Merlot, Cabernet Sauvignon, Busuioacă de Bohotin, Oporto and for table grapes (TG) from the cultivars Chasselas doré and Chasselas rose, Muscat Hamburg, Coarnă neagră.

VZ3 is designated for the growing of grapes for QRW and TWW from the cultivars Cabernet Sauvignon, Fetească neagră, Pinot noir, Merlot, Busuioaca de Bohotin, Burgund Mare, for QWW and TWW from the varieties Fetească albă, Riesling Italian, Aligote, Fetească regală, Pinot gris, Sauvignon, Muscat Ottonel, Grasă de Cotnari, Tamaioasa românească, Saint Emilion and for TG from the varieties Chasselas doré and Chasselas rose, Muscat Hamburg, Muscat de Adda, Coarnă neagră, Afuz Ali, Italia, Cardinal.

The smallest VZ of Romania, VZ4, is mainly designated for QRW from the cultivars Cabernet Sauvignon, Pinot noir, Merlot, Burgund Mare, Cadarcă, but QRW and TWW from the cultivars Riesling Italian, Fetească regală, Sauvignon, Muscat Ottonel, Creață, Majarca albă, and Steinschiller and TG from the cultivars Chasselas doré and Chasselas rose, Muscat Hamburg, Muscat de Adda are also grown.

The cultivars of the VZ5 are designated for QRW from the cultivars Cabernet Sauvignon, Pinot noir, Merlot, Burgund Mare, Cadarcă, for QRW and TWW from the cultivars Riesling Italian, Fetească regală, Muscat Ottonel, Mustoasă de Măderat, Furmint, Pinot gris, and Traminer roz and TG from the cultivars Chasselas doré and Chasselas rose, Muscat Hamburg. The white cultivars of VZ5 are also used for distillates, and the cultivars Fetească albă, Fetească regală and Iordană for sparkling wines.

The viticultural zone of Dobrogea hills (VZ6) is represented by a large assortment of wines and table grapes and cultivars for raisins (Sultanina). Thus, for QWW and TWW, the cultivars Pinot gris, Chardonnay, Muscat Ottonel, Riesling Italian, Sauvignon, Fetească regală, and Aligote are grown, for QRW and TRW, the cultivars Cabernet Sauvignon, Pinot noir, Merlot, Băbească neagră, Sangiovese, Burgund mare, and for TG, the cultivars Perla de Csaba, Italia, Chasselas doré and Chasselas rose, Cardinal, Muscat Hamburg, Muscat de Adda, Afuz Ali.

The Danube Terraces (VZ7) are mainly cultivated with TG (Perla de Csaba, Italia, Chasselas doré and Chasselas rose, Cardinal, Muscat Hamburg, Muscat de Adda, Afuz Ali) and also the only one in Romania for the seedless raisins. QRW and TRW from the cultivars Cabernet Sauvignon, Pinot noir, Merlot, Burgund mare and QWW and TWW from the cultivars Pinot gris, Riesling Italian, Fetească regală, Sauvignon are also produced here.

On the VZ8, represented by the sands and other suitable terrains from the South of Romania, grapes for TRW and QRW (Rosioara, Sangiovese, Băbească neagră, Cabernet Sauvignon, Merlot, Burgund Mare) for TWW and QWW (St. Emilion, Rkatiteli, Fetească regală, Riesling Italian, Sauvignon, Aligote) and for TG (Muscat Perla de Csaba, Italia, Perla de Csaba, Chasselas doré and Chasselas rose, Cardinal, Muscat Hamburg, Muscat de Adda, Afuz Ali, Coarnă neagră) are cultivated [100].

The presented assortment of wines for all the VZ is completed and extended by newly created cultivars and the acclimatization of other international cultivars. Climate change has generated a dynamic of the cultivar assortment grown [91], and the general trend is the replacement of the white cultivars with the red ones and the increase of altitude for the white types [91].

\section{Grapevine Cultivation and Wine Production in Târnave Vineyards}

Located at the intersection of the geographical coordinates of $46^{\circ}-47^{\circ}$ Northern latitude and $23^{\circ}-24^{\circ}$ Eastern longitude, Târnave vineyards are part of the viticultural zone 1 of Romania. They are situated on the Transylvanian Plateau [101-104]. The most significant viticultural area of Transylvania, the prestigious Târnave vineyard, named so because most of the vineyards are located on the slopes that delineate the valleys of the rivers Târnava Mare and Târnava Mica [101,103,104], is known and appreciated for its quality wines with a specific flavor and a good sugar/acidity balance [101,102,104]. From the environmental 
point of view, grapevine finds good conditions and a good growing season here, with the Târnave vineyard being part of the Tara Vinului [102,105]. Tara Vinului, The Land of Wine or Weinland, is the wine route of Alba County spreading between the rivers Mures, Tarnava Mare, and Tarnava Mica, including the vineyards: Aiud, Alba-Iulia, Sebeș-Apold, and Târnave, and is located on 18 administrative-territorial units (ATU) out of Romania's 78 ATUs [106], with 90 localities out of which five are municipalities and towns with the surrounding villages [106]. In turn, the Târnave vineyard includes five wine centers: Blaj, Jidvei, Mediaș Târnăveni, Zagăr and Valea Nirajului.

SCDVV Blaj, the viticultural and wine research center of the Tarnave vineyard, is one of the main actors of the research and development in the field in Transylvania [106]. In Transylvania, viticulture has been practiced since antiquity, perpetuating and developing ever since the migration of people during the feudal period up to now [101,103,107]. The interest of the inhabitants in this vineyard area has been and is shown by both the grapevine cultivation and the winemaking [103]. The existence of an ancient, well-developed, wellknown viticulture in the center of Transylvania imposed the necessity of studying and establishing on a scientific basis the basic assortment specific to this area $[103,108]$. For this purpose, it was necessary to set up experimental wine-growing stations, which would contribute to the scientific solution of the requirements related to the quantitative increase and the quality of the grape and wine production [102,103,108,109]. In this context, in the territory of the Romanian State Reserve Crăciunelul de Jos, 7 km away from Blaj, in 1946, it was decided to establish the Viticultural Experimental Station Crăciunelu de Jos [108]. The research-development activity initiated by the academician Gheorghe Ionescu Şiseşti was continued. Considering the decision of the Department of Agriculture and State Domains, in 1929, to establish the Institute of Agricultural Research of Romania (ICAR) and being located in the center of one of the oldest vineyards "Tîrnave Vineyard", SCDVV Blaj had an undeniable role in the development and modernization of viticulture in Transylvania [108].

The importance of the wine region from the Transylvanian plateau is reflected in the area, the grapevine cultivars and clones planted here, and also in the quality of dry, semi-dry, semi-sweet, semi-aromatic, aromatic, and sparkling POD and PGI original and noble wines obtained from the established cultivars Fetească albă, Fetească regală, Riesling Italian, Sauvignon blanc, Muscat Ottonel, Neuburger, etc. [101-103,110]. As the qualitative assessment results indicate, the grapevine cultivars created at SCDVV Blaj have very good suitability for this area. In terms of quality rating, the clones Fetească Regală $21 \mathrm{Bl}$, Muscat Ottonel 12 Bl, and Sauvignon Blanc 9 Bl display particularly improved characters compared with the parental cultivars [103]. As a research hub for viticulture and winemaking in Transylvania, new cultivars and clones are developed and homologated at SCDVV Blaj [111-116] (Table 4). In 2020, 25 wine-grape cultivars: 11 cultivars, including 8 white cultivars and 3 red cultivars; 13 clones for white wine, homologated at SCDVV Blaj; and 1 red hybrid were grown and used for winemaking at SCDVV Blaj [117]. Table 4 presents the wine grapevine cultivars and clones homologated and cultivated at SCDVV Blaj. Some of the cultivars and clones homologated at SCDVV Blaj have tolerance to cryptogamic diseases and cold, which are valuable characteristics for sustainable grapevine growing. 
Table 4. Grapevine cultivars homologated and cultivated at SCDVV Blaj, Târnave Vineyard, Romania.

\begin{tabular}{cccc}
\hline $\begin{array}{c}\text { Cultivar-Homologation } \\
\text { Year }\end{array}$ & $\begin{array}{c}\text { Colour of the } \\
\text { Grape's Skin }\end{array}$ & Usage & Genetic Ortigin \\
\hline & & Homologated cultivars developed at SCDVV Blaj \\
\hline Roze Blaj-2020 & Rosé & Grape cultivar for & $\begin{array}{c}\text { Sexuate intercrossing of two elites } \\
8-33-44 \text { (Iordană } \times \text { Traminer roz) } \\
\end{array}$ \\
& white wine & $\times 51-19$ (Raisin de Saint Pierre $\times$ \\
& & Perla de Csaba).
\end{tabular}

\begin{tabular}{|c|c|c|c|}
\hline Rubin-2007 & Red & $\begin{array}{c}\text { Grape cultivar for red } \\
\text { wine }\end{array}$ & $\begin{array}{l}\text { Sexuate interspecific hybridization } \\
\text { between the Traminer roz cultivar } \\
\text { and a hybrid descendant (Seyve } \\
\text { Villard } 12375 \times \text { Regina viilor) }\end{array}$ \\
\hline
\end{tabular}

High richness and yield; suitable for white, dry or semi-dry superior quality wines; high tolerance to drought due to leaf structure; increased tolerance to cryptogamic diseases due to the tight berry skin.

High tolerance to diseases and good tolerance to cold; favorable results for economic viticulture, especially for family use and for replacing the direct-producer hybrids; recommended for leisure vineyards.

High yielding capacity; good potential to accumulate sugars; good tolerance to cold (buds' dead less than $25 \%$ at -20 ), drought and diseases with respect to other cultivars specific to $V Z_{1}$ (Transylvania), preserving its foliar apparatus and grapes in a normal stage. Because of its late bud break it is more protected against the late spring frosts.

\section{Homologated cultivars developed at SCDVV Blaj}

Selena-1995 cultivar for
white wine

Vitis vinifera ssp. sativa L. Sexuate hybridization between Iordană cultivars $\times$ Traminer roz
High fertility and yieldingness; ensures the production of high quality dry and semi-dry white wines; high to very good tolerance to cold and several cryptogamic diseases.

Maturation of the vine ropes is done at a superior level, favoring the cold tolerance increase, while the fertile region is placed at the very base of the cane. The shoot
Vitis vinifera ssp. sativa L. (Traminer roz $\times$ Iordană $) \times($ Raisin de Saint Piere $\times$ Perlă de Csaba)

$\begin{array}{ccc}\text { Blasius-1994 White } & \begin{array}{c}\text { Grape cultivar for } \\ \text { white wine }\end{array} & \begin{array}{c}\text { Traminer roz } \times \text { Iordană }) \times(\text { Raisin } \\ \text { de Saint Piere } \times \text { Perlă de Csaba })\end{array}\end{array}$
maturation is done at the shoot tip, which favors the tolerance to cold increasing, and the fertile buds are at the base of the cane. Succulent pulp, with a sweet-sour taste, favorable for wine equilibrium sugars/acidity.

High tolerance to cold and cryptogamic diseases; high fertility and yieldingness; ensures the

\begin{tabular}{|c|c|c|c|}
\hline Radames-1993 & Rosé & $\begin{array}{l}\text { Grape cultivar for } \\
\text { white wine }\end{array}$ & $\begin{array}{c}\text { Interspecific hybrid Traminer roz } \\
\times \text { (Seyve Villard 12.375) }\end{array}$ \\
\hline
\end{tabular}
production of dry white wines for current consumption or wine-distillates; recommended for leisure farms.

Ensures the production of superior, table and sparkling red wines. Recommended in Târnave and Aiud vineyards and other Amurg-1989 Dark-red $\quad \begin{gathered}\text { Grape cultivar for red } \\ \text { wine }\end{gathered}$
Vitis vinifera ssp. sativa L. Muscat de Hamburg $\times$ Cabernet Sauvignon viticultural zones with favorable conditions for producing red wines; medium tolerance to cryptogamic diseases and cold.

Good tolerance to cryptogamic diseases and cold; recommended for wine-distillate. 
Table 4. Cont.

\begin{tabular}{|c|c|c|c|c|}
\hline $\begin{array}{c}\text { Cultivar-Homologation } \\
\text { Year }\end{array}$ & $\begin{array}{l}\text { Colour of the } \\
\text { Grape's Skin }\end{array}$ & Usage & Genetic Origin & Characteristics \\
\hline \multicolumn{5}{|c|}{ Homologated clones developed at SCDVV Blaj } \\
\hline $\begin{array}{c}\text { Pinot gris } 11 \mathrm{Bl} . \\
2020\end{array}$ & White & $\begin{array}{l}\text { Grape cultivar for } \\
\text { white wine }\end{array}$ & $\begin{array}{c}\text { Vitis vinifera ssp. sativa L. Pinot } \\
\text { gris }\end{array}$ & \multirow{6}{*}{$\begin{array}{l}\text { Superior qualities compared to the } \\
\text { parental cultivar population. } \\
\text { Better fertility; it does not show } \\
\text { millerandage (or shot berries, hens, } \\
\text { and chicks and pumpkins and } \\
\text { peas) phenomena has resistance to } \\
\text { diseases. Ensures the production } \\
\text { of high-quality white wines with } \\
\text { POD potential. }\end{array}$} \\
\hline $\begin{array}{c}\text { Fetească albă } 29 \text { Bl. } \\
2006\end{array}$ & White & $\begin{array}{l}\text { Grape cultivar for } \\
\text { white wine }\end{array}$ & $\begin{array}{l}\text { Vitis vinifera ssp. sativa L. } \\
\text { Population of the Fetească albă } \\
\text { cultivar }\end{array}$ & \\
\hline $\begin{array}{c}\text { Iordană 9-1 Bl. } \\
2006\end{array}$ & White & $\begin{array}{l}\text { Grape cultivar for } \\
\text { white wine }\end{array}$ & $\begin{array}{l}\text { Vitis vinifera ssp. sativa L. } \\
\text { Population of the Iordană cultivar }\end{array}$ & \\
\hline $\begin{array}{l}\text { Riesling de Rhin 7-2 Bl. } \\
\qquad 2006\end{array}$ & White & $\begin{array}{l}\text { Grape cultivars for } \\
\text { white wine }\end{array}$ & $\begin{array}{l}\text { Vitis vinifera ssp. sativa L. } \\
\text { Population Riesling de Rhin } \\
\text { cultivar }\end{array}$ & \\
\hline $\begin{array}{l}\text { Muscat Ottonel } 12 \text { Bl. } \\
1995\end{array}$ & White & $\begin{array}{l}\text { Grape cultivar for } \\
\text { white wine }\end{array}$ & $\begin{array}{l}\text { Vitis vinifera ssp. sativa L. } \\
\text { Population of the Muscat Ottonel } \\
\text { cultivar }\end{array}$ & \\
\hline $\begin{array}{c}\text { Neuburger-10 Bl. } \\
1993\end{array}$ & White & $\begin{array}{l}\text { Grape cultivar for } \\
\text { white wine }\end{array}$ & $\begin{array}{l}\text { Vitis vinifera ssp. sativa L. } \\
\text { Population of the Neuburger } \\
\text { cultivar }\end{array}$ & \\
\hline \multicolumn{5}{|c|}{ Homologated clones developed at SCDVV Blaj } \\
\hline $\begin{array}{l}\text { Riesling Italian-3 Bl. } \\
1983\end{array}$ & White & $\begin{array}{l}\text { Grape cultivar for } \\
\text { white wine }\end{array}$ & $\begin{array}{c}\text { Vitis vinifera ssp. sativa L. } \\
\text { Population of the Riesling Italian } \\
\text { cultivar }\end{array}$ & \multirow{5}{*}{$\begin{array}{l}\text { Superior qualities compared to the } \\
\text { parental cultivar population. } \\
\text { Better fertility; does not show } \\
\text { millerandage (or shot berries, hens } \\
\text { and chicks and pumpkins and } \\
\text { peas) phenomena has resistance to } \\
\text { diseases. It ensures the production } \\
\text { of high-quality white wines with } \\
\text { POD potential. }\end{array}$} \\
\hline $\begin{array}{l}\text { Fetească regală-21 Bl. } \\
1979\end{array}$ & White & $\begin{array}{l}\text { Grape cultivar for } \\
\text { white wine }\end{array}$ & $\begin{array}{l}\text { Vitis vinifera ssp. sativa L. } \\
\text { Population of the Fetească regală } \\
\text { cultivar }\end{array}$ & \\
\hline $\begin{array}{c}\text { Traminer roz-60 Bl. } \\
1975\end{array}$ & Pink & $\begin{array}{l}\text { Grape cultivar for } \\
\text { white wine }\end{array}$ & $\begin{array}{l}\text { Vitis vinifera ssp. sativa L. } \\
\text { Population of the Traminer roz } \\
\text { cultivar }\end{array}$ & \\
\hline $\begin{array}{c}\text { Pinot gris-34 Bl. } \\
1975\end{array}$ & White & $\begin{array}{l}\text { Grape cultivar for } \\
\text { white wine }\end{array}$ & $\begin{array}{l}\text { Vitis vinifera ssp. sativa L. } \\
\text { Population of the Pinot gris } \\
\text { cultivar }\end{array}$ & \\
\hline $\begin{array}{l}\text { Sauvignon gris-9 Bl. } \\
1975\end{array}$ & White & $\begin{array}{l}\text { Grape cultivar for } \\
\text { white wine }\end{array}$ & $\begin{array}{c}\text { Vitis vinifera ssp. sativa L. } \\
\text { Population of the Sauvignon blanc } \\
\text { cultivar }\end{array}$ & \\
\hline
\end{tabular}

\section{Perspectives on the Culture in Târnave Vineyards of Amurg-A Disease Tolerant Autochthonous Grapevine Cultivar for POD Red and Rosé Wines}

Generally, in the Blaj Wine Center, the climatic conditions favor the exceptional viticultural value and authenticity of the wide cultivar of the cultivated grapevine as well as of the wines produced in this area [103]. The predominant soil in this vineyard is luvisol [104].

\subsection{The Climate Change Context \\ 6.1.1. Period 1975-2007}

The climate of the vineyards in the Transylvanian Plateau is characterized by low values of the thermal balance and by a relatively short vegetation period [101]. The average daily temperature above $10{ }^{\circ} \mathrm{C}$ is recorded in spring, during the second day of April. In autumn, it falls below this limit, starting from the second day of October [101]. The number of days with active temperatures is 172 , with limits between 154 and 182 days [101]. The annual sum of temperature is between $3050{ }^{\circ} \mathrm{C}$ and $3592^{\circ} \mathrm{C}$, and during the vegetation period, it has values between $1963^{\circ} \mathrm{C}$ and $3335^{\circ} \mathrm{C}$ [101]. The useful thermal balance records, on average, $1205^{\circ} \mathrm{C}$ with oscillations between $952^{\circ} \mathrm{C}$ and $1479{ }^{\circ} \mathrm{C}$ [101]. The average annual temperature against which one performed the data analysis, as a reference value, is $9{ }^{\circ} \mathrm{C}$, calculated for the period 1975-1990 [101]. The sum of hours of sunshine during the vegetation period is between 1128 and 1859 h, with an average value of $1371 \mathrm{~h} \mathrm{[101]}$. Autumns 
are often long and sunny, allowing the accumulation of increased amounts of sugars and flavors, while the acidity remains relatively high [101]. The amount of annual precipitation ranges between 542 and $872 \mathrm{~mm}$, and during the vegetation period, has an average value of $401 \mathrm{~mm}$ [101]. Rainfall is unevenly distributed during the year, so there are periods of rain that often make it challenging to combat cryptogamic diseases effectively [101]. For instance, Botrytis attacks have been quite frequent, favored during the autumn, by the persistent fog that characterizes this area [101]. Plantations in the Târnave vineyard are frequently affected by low winter temperatures, temperatures that often fall below the grapevine's resistance limit [101]. The plantations located at the base of the slopes and on the valleys are affected, as well as those situated on open plateaus [101]. Apart from the low winter temperatures, there are favorable hoar conditions in this area. In addition, there are late spring and early autumn frosts. Hail also causes damage every year, but it is not very significant [101].

\subsubsection{Period 2000-2020}

The main climatic data (minimum absolute temperature, maximum absolute temperature, medium temperature, rainfall, and thermal balance) for the period 2000-2020, having as a reference the multi-annual average for the years 1975-2010, are presented in Figures 4-6. The annual sum of temperature degrees, the global thermal balance, is between 3043.7 (2004) and $3682.5^{\circ} \mathrm{C}(2015)$ with an average value of $3289.7^{\circ} \mathrm{C}$. In the vegetation period, the active thermal balance has values between 2950 (2010) and $3896.5^{\circ} \mathrm{C}$ (2004). The useful thermal balance registers on average $1451.5^{\circ} \mathrm{C}$, with oscillations between 1246.5 (2004) and $1733^{\circ} \mathrm{C}(2012)$, as we depicted in Figure 5.

The average value (period 2000-2020) for the average annual temperature is $10.6{ }^{\circ} \mathrm{C}$, with oscillations between 8.6 (2016) and $11.9{ }^{\circ} \mathrm{C}$ (2019). The average annual temperature, against which the data analysis was performed as a reference value, is $10.1^{\circ} \mathrm{C}$ (monthly) and, respectively, $17.2^{\circ} \mathrm{C}$ (during vegetation), calculated for the period 1975-2012 (Figure 4).

The average annual rainfall value for the period 2000-2020 was $618.3 \mathrm{~mm}$, with a maximum recorded in 2016 of $892 \mathrm{~mm}$ and a minimum of $303.9 \mathrm{~mm}$ registered for the year 2011. The precipitations during the vegetation period (April-September) had the average value of $427.6 \mathrm{~mm}$ with a maximum of $647 \mathrm{~mm}$ recorded in 2016 and a minimum of $201.8 \mathrm{~mm}$ for the year 2011. We presented the evolution of the rainfall in Figure 6.

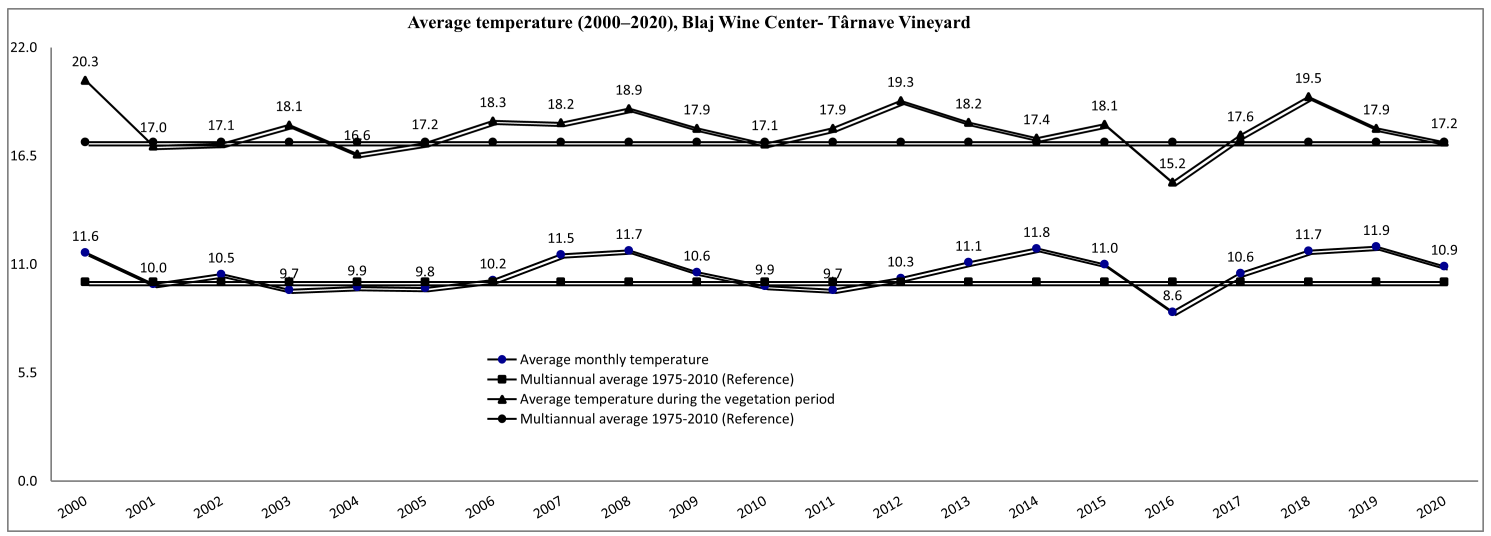

Figure 4. Average temperature in the period 2000-2020, Blaj Wine Center, Târnave Vineyard. 


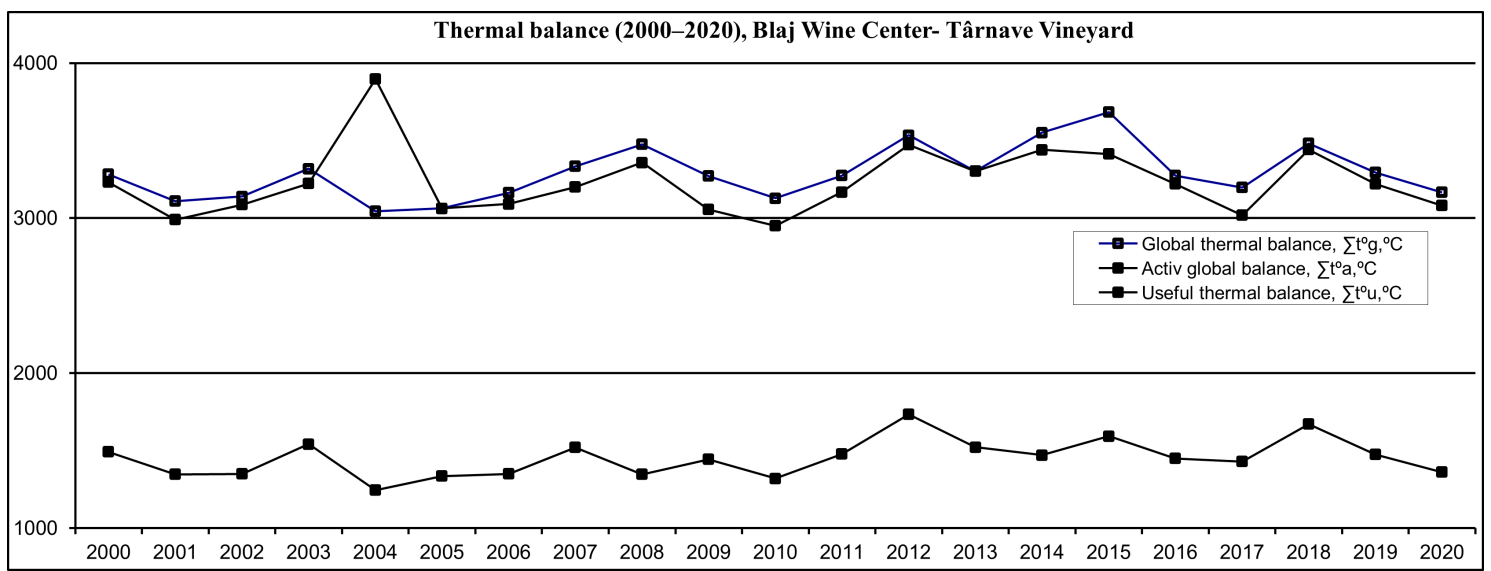

Figure 5. Thermal balance in the period 2000-2020, Blaj Wine Center, Târnave Vineyard.

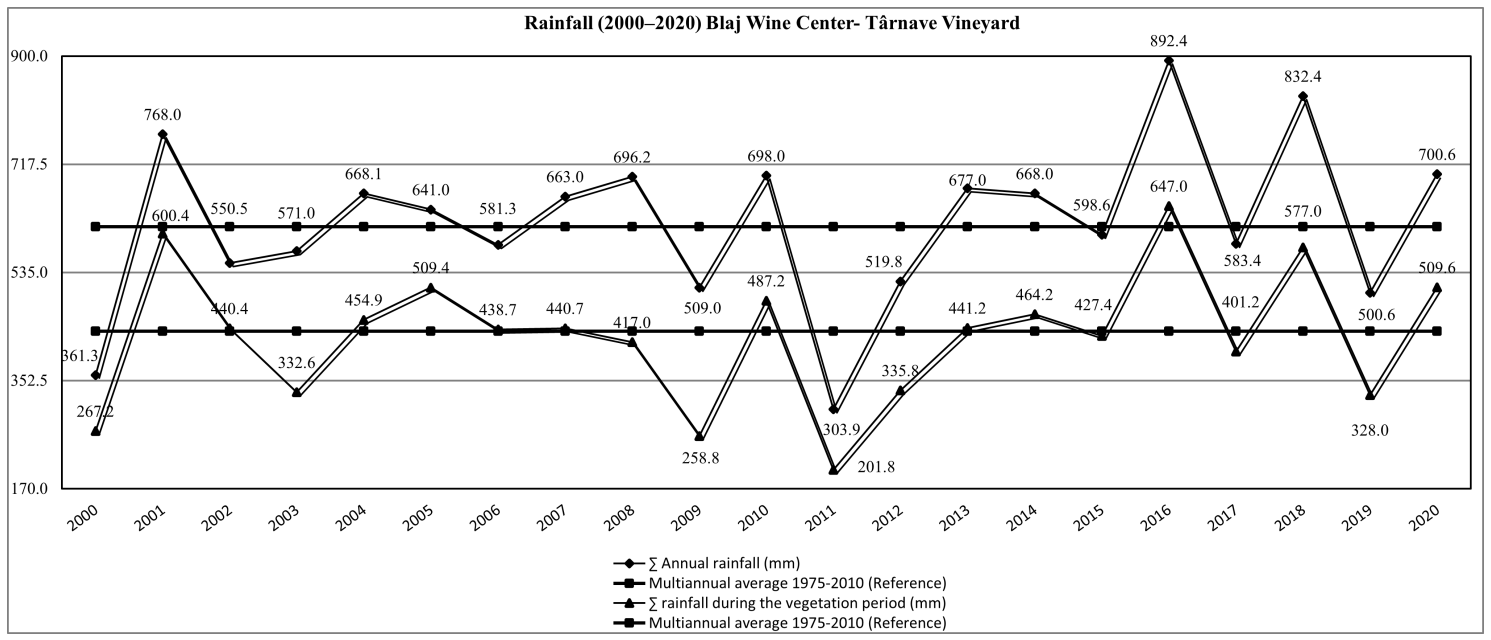

Figure 6. Rainfall in the period 2000-2020, Blaj Wine Center, Târnave Vineyard.

6.1.3. Comparing the Two Periods (1975-2007 and 2000-2020)

After examining the two periods (1975-2007 and 2000-2020), we can remark that, for the Târnave vineyard, the climate changed as follows:

- The period of active vegetation increased by approx. 15-20 days [99,118,119];

- The average annual temperature increased by $1-1.5^{\circ} \mathrm{C}[99,118,119]$;

- The amount of useful temperatures increased (useful thermal balance for the vine); $[99,118,119]$

- $\quad$ Frost periods have reduced $[99,118,119]$.

\section{Grapevine Amurg Cultivar}

Amurg cultivar was obtained through the efforts of Csavossy Gheorghe, a researcher at the Research Station for Viticulture and Enology Blaj by intraspecific sexual hybridization between the acclimatized genitors Muscat de Hamburg and Cabernet Sauvignon cultivars with a unique Transylvanian terroir and was homologated in 1989 [110,120].

\subsection{Morphological Characteristics}

Amurg grapevine cultivar has a white-green, fluffy rosette (vegetative shoots), and its flower is a normal hermaphrodite. The adult leaf is round, large, with 3-5 lobes, and slightly hairy on the underside [110]. The lateral sinuses of the leaf are circularly closed, the petiole sinus is lyre-shaped and the petiole point is reddish [110]. The leaf edge has large, sharp teeth [110]. The grape is medium in size, cylindrical-conical, winged, compact [110]. The berry is ovoid, slightly elongated, red-blue, and has a juicy core [110]. 


\subsection{Agrobiological and Technological Characteristics}

Amurg is a cultivar of medium to great vigor, with the maturation of the grapes in the 5th epoch [110] (Figure 7). It shows tolerance to low winter temperatures, up to minus $22{ }^{\circ} \mathrm{C}$ and is resistant to both downy mildew and Botrytis [110].

The fertility of the cultivar is low-medium, it forms only $35-48 \%$ fertile shoots (Figure 7), and the fertility coefficients have average values of 0.8 for the relative one and 1.7 for the absolute one [110]. The average weight of a grape is $260 \mathrm{~g}$, the weight of 100 berries is $261 \mathrm{~g}$, and the potential for sugar accumulation is $178-197 \mathrm{~g} / \mathrm{L}$, accompanied by a must acidity of 4.5-5.5 g/ $\mathrm{L} \mathrm{H}_{2} \mathrm{SO}_{4}$ [121]. We highlighted in Table 5 that Amurg wine has an acidity of $5.92 \mathrm{~g} / \mathrm{L} \mathrm{H}_{2} \mathrm{SO}_{4}$ (Table 5) and is characterized by a content of $12.38 \%$ alcohol volume and $21.18 \mathrm{~g} / \mathrm{L}$ non-reducing dry extract. The grape production obtained is on average $12-15 \mathrm{t} / \mathrm{ha}$, from which a POD wine is obtained that can be used as a raw material for rosé sparkling wines (Figure 7) [121].

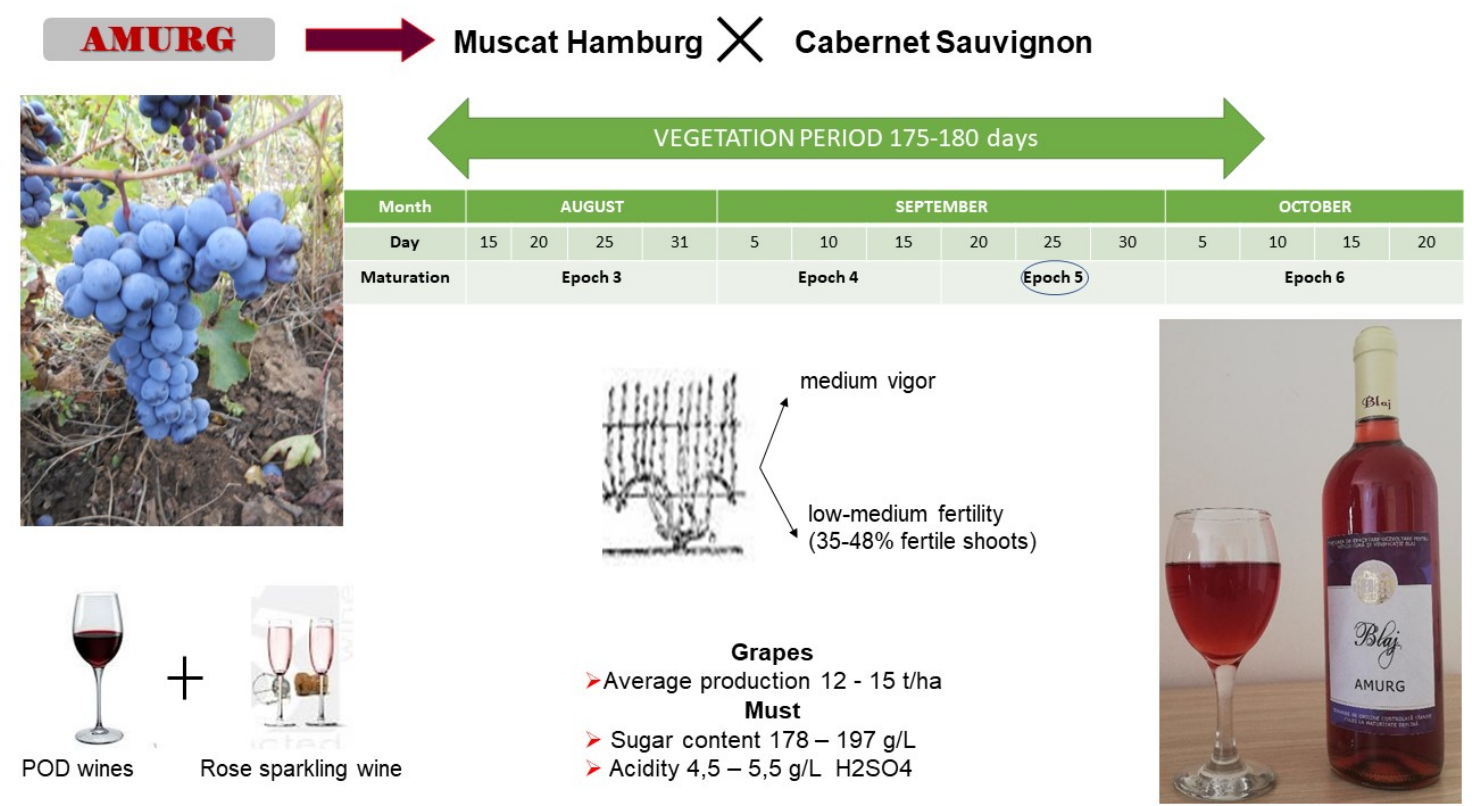

Figure 7. Agrobiological and technological characteristics of the Amurg grapevine cultivar. Adapted from [121].

Table 5. Physicochemical analyses of Amurg wine.

\begin{tabular}{|c|c|c|c|c|c|c|c|c|}
\hline $\begin{array}{l}\text { Alcohol (\% } \\
\text { vol.) }\end{array}$ & $\begin{array}{c}\text { Inverted } \\
\text { Total Sugars } \\
(\mathrm{g} / \mathrm{L})\end{array}$ & $\begin{array}{c}\text { Total } \\
\text { Acidity }(\mathrm{g} / \mathrm{L} \\
\left.\mathrm{H}_{2} \mathrm{SO}_{4}\right)\end{array}$ & $\begin{array}{c}\text { Volatile } \\
\text { Acidity (g/L } \\
\text { Acetic Acid) }\end{array}$ & $\begin{array}{c}\mathrm{SO}_{2} \text { Free } \\
(\mathrm{mg} / \mathrm{L})\end{array}$ & $\begin{array}{c}\mathrm{SO}_{2} \text { Total } \\
(\mathrm{mg} / \mathrm{L})\end{array}$ & $\begin{array}{c}\text { Total Dry } \\
\text { Extract }(\mathrm{g} / \mathrm{L})\end{array}$ & $\begin{array}{c}\text { Non- } \\
\text { Reducing } \\
\text { Dry Extract } \\
(\mathrm{g} / \mathrm{L})\end{array}$ & $\begin{array}{c}\text { Glucose + } \\
\text { Fructose } \\
(\mathrm{g} / \mathrm{L})\end{array}$ \\
\hline 12.38 & 1.52 & 5.92 & 0.35 & 22.50 & 110.00 & 22.70 & 21.18 & 0.35 \\
\hline
\end{tabular}

In Table 6, we present the sensorial characteristics of the Amurg wine.

Table 6. Sensorial description of the Amurg wine.

\begin{tabular}{cc}
\hline Parameters & Characteristics \\
\hline Appearance & clear, glossy \\
\hline Colour & cherry \\
\hline Aroma/ Bouquet & floral notes aromas and fresh fruit aromas \\
\hline Taste & pleasant, dry, light raspberry aroma, soft wine, balanced \\
\hline Acidity & low \\
\hline
\end{tabular}




\section{Amurg's Diseases Tolerance and Resistance}

Although much of the climate change debate has been centered on temperature effects, other concerns impacting the production of grapes, wines, and their quality include shifting viticulture due to elevated levels of $\mathrm{CO}_{2}$ in the environment, additional moisture pressures in water-limited areas, as well as changes in the presence or severity of pests and grapevine diseases [39]. Some of the essential qualities of the Amurg cultivar are the resistance to low winter temperatures and the tolerance or even resistance to some diseases like black rot. The resistance or tolerance of grapevine to such diseases represents a critical feature that reflects the sustainability of their cultivation because, in this way, the fungicides treatments are lowered.

Guignardia bidwellii (Ellis) Viala and Ravaz, the pathogen of the grapevine's black rot, is at the present time one of the most important fungal pathogens found in the vineyards worldwide [98]. The loss of harvest associated with this disease can vary from 5 to $100 \%$, depending on climate, the reserve of pathogen's inoculum, and sensitivity of cultivated cultivars $[98,122,123]$. Romania's vineyards had sporadic and economically minor black rot outbreaks by the year 2006 [98]. In recent years, the incidence and severity of the disease in particular in the vineyards of Central Transylvania have been steadily increasing due to climate change, leading to substantial declines in productivity, with direct repercussions for wine quality and grapevine growers' incomes in the region, [98,124,125]. Genetic stamina is the most rational and economical way of controlling this disease, particularly for plantations cultivated in a sustainable system [126,127]; although, at present, there are various methods and means of preventing and countering the attack of black rot and other diseases, e.g., smart viticulture [98].

In this framework, the results of the susceptibility/tolerance at the attack of black rot of cultivars homologated at SCDVV Blaj (for the period 2016-2018) revealed the tolerance of Amurg (Attack Degree $=0.25 \%$ ) compared with other autochthonous cultivars [98] A correlation between high rainfall, above $10 \mathrm{~mm}$, high temperatures above $15{ }^{\circ} \mathrm{C}$ and infection pressure, incidence and severity of the Guignardia bidwellii attack was noticed in all three years [98]. For example, in June and July of 2016-2018, the attack frequency (F) on the clones Fetească regală-21 Bl. (F=90\%), Fetească albă-29 Bl. (F = 95\%), Muscat Ottonel-12 Bl. $(\mathrm{F}=90 \%)$ and Pinot gris-34 Bl. $(\mathrm{F}=85 \%)$ increased by average values of $85-90 \%$ due to a few weeks with intense daily precipitation combined with high temperatures [98]. The frequency of the attack was below $5 \%$ for the cultivars Rubin $(\mathrm{F}=2.80 \%)$ and Amurg $(\mathrm{F}=4.50 \%)$ for the same climatic conditions [98]. For the Fetească albă-29 Bl. $(\mathrm{I}=37 \%)$ and Muscat Ottonel-12 Bl. ( $\mathrm{I}=43 \%$ ) clones, the intensity (I) of the black rot attack was especially high, while for the Rubin and Amurg cultivars, the intensity was much lower with an average of $4.80 \%$, and $5.60 \%$, respectively [98].

Table 7 reviews the results concerning attack frequency and intensity for each of the cultivars involved in the study.

Table 7. Guignardia bidwellii attack frequency and intensity on grape cultivars at SCCDV Blaj. Adapted from [98].

\begin{tabular}{cccc}
\hline Cultivar & $\begin{array}{c}\text { Attack Frequency (F) } \\
\mathbf{( \% )}\end{array}$ & Intensity (I) (\%) & Climatic Conditions \\
\cline { 1 - 3 } Fetească regală 21 Bl & 90 & 35 & few weeks with intense \\
Fetească albă 29 Bl & 95 & 37 & $\begin{array}{c}\text { daily precipitation } \\
\text { combined with high } \\
\text { temperatures }\end{array}$ \\
\cline { 1 - 3 } Muscat Ottonel 12 Bl & 90 & 36 & \\
\hline Pinot gris 34 Bl & 85 & 4.8 & 5.6 \\
\hline Rubin & 2.8 & &
\end{tabular}


9. Designing and Developing a New Climate Change-Based Precision Viticulture (CCPV) Technology Based on the Following Concepts: IoT, Cloud Computing, Data Cyber-Security, Blockchain (for Amurg Vine Cultivar Traceability)

\subsection{Context, Approach and Objectives}

Amurg red grape cultivar is already cultivated on the experimental research plots at SCDVV Blaj. Since its homologation in 1989, this cultivar was used in studies of productivity, resistance to pests, and agroecological technologies.

We propose a new approach based on deploying an IoT-based platform that monitors the cultivated area and the productive cycle of grapes. Moreover, our proposal aims to support the farmer to ensure the quality of grape production from the point of view of field action planning and grape preservation. The sensing infrastructure is based on Wireless Sensor Networks (WSN) and remote terminal units deployed in the field. Further, a central unit collects the data and forwards it to the component that performs inferences to recommend on-time actions that one must take to ensure the grapes' quality.

Through this section, we also propose the use of another network for the vineyard at SCDVV Blaj that allows the monitoring of the grapevines micro-climate to extend the cultivation of the Amurg red grapes cultivar in Transylvania for obtaining PDO red wines. One of the proposed system's goals is to gain insight into potential relationships among the vineyard macro-climate Amurg cultivar and red grapevine micro-climate to provide support to the specialists in making decisions concerning the necessary actions that one must take during the plants' growing stages.

The design will follow an efficient CCPV-driven approach as a pathway to:

- (a) Increase grapevine productivity and income,

- (b) Adapt the Amurg cultivar to climate extremes in the Transylvania region,

- (c) Support new technologies in acquiring data.

CCPV mitigates the challenges of climate change in wine production. The CCPVdriven architecture consists of two modules, the physical world (vineyards) and the digital world (smart applications for winemakers):

- (a) The data collection system, which provides the advanced data collection functions and the autonomous monitoring functions, including smart sensors and tracking devices, aerial sensing systems with high-accuracy monitoring features, weather and climate data control with forecasting features, energy management, and harvesting system gateway. Finally, it will allow event and data analytics based on Cloud features.

- (b) Software, which encloses all the user-friendly services and applications, such as anomaly detection, pest detection, irrigation, and fertilization recommendations as a service, and the farming economics.

The proposed approach will bring an important input to extending the cultivation of this cultivar in Transylvania by designing and developing a new technology CCPV applied in the vineyard for smart viticulture based on the following concept: IoT, cloud computing, data cybersecurity, blockchain (for Amurg vine cultivar traceability).

The main objectives of the system are:

- $\quad$ To design and provide a specific framework to analyze the Amurg cultivar by fostering its terroir;

- To enhance plant health assessment methods;

- To limit the use of fertilizers to the necessary quantities depending on the plant status;

- To promote the best practices towards the resilience and mitigation of climate changes in the vineyard. Knowledge dissemination of best practices is of paramount importance for their swift adoption in Romania's vineyards.

\subsection{System Architecture and Workflow}

In Figure 8, we depicted the overall CCPV-driven architecture for monitoring and tracing the Amurg cultivar. 


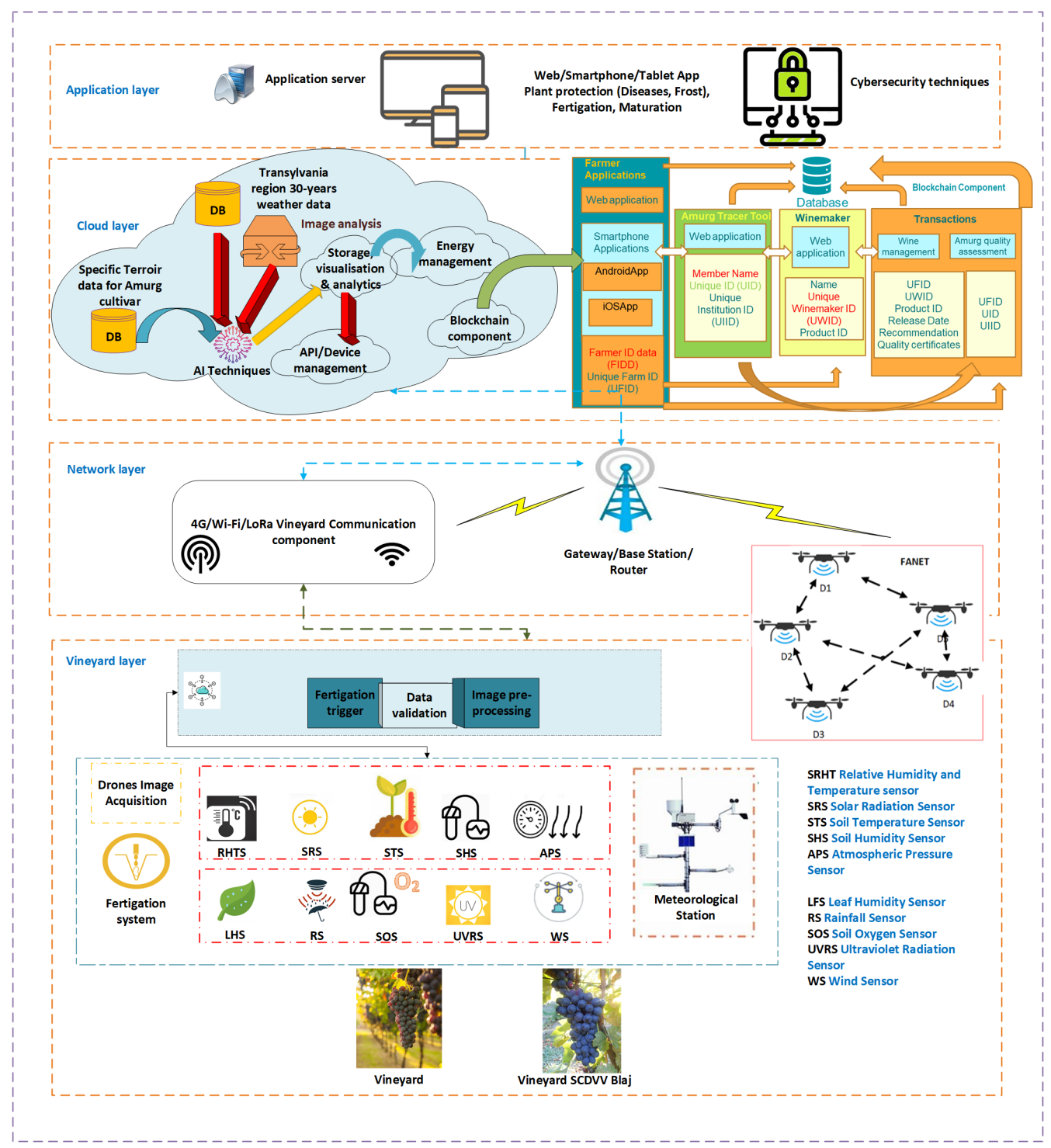

Figure 8. Proposed CCPV IoT architecture for the Amurg cultivar.

The architecture consists of four main layers: Vineyard, Network, Cloud, and Application layers.

\subsubsection{Vineyard Layer}

The system requires a multiple data resource integration, which is a consequence of the large number of devices, the so-called "Things", which belong to the Vineyard layer. This layer is based on the IoT Perception layer or Devices layer previously proposed in IoT architectures $[128,129]$. Among the adopted devices, we mention drones, which are also components of the following layer (Network layer) because they can act both as data/image collectors and dynamic spraying devices (thus, belonging to Vineyard layer) and network relays (thus, belonging to Network layer). In addition, the Vineyard layer includes the static fertigation system and the sensing devices. The innovative component of some of these sensors is combined with other necessary technologies, such that a selflearning platform is developed. The platform is further provided with pseudo-real-time and real-time analytical capacity and with predictive capabilities.

Data collection is done by deploying intelligent devices that collect viticulture-specific data that is turned into valuable information. The employed devices monitor the parameters that are used to predict ripening stages and the production quality. In addition, a multi-spectral camera collects different spectral images [130]. The integration of all 
these devices ensures data diversity. It triggers many concerns related to the physical devices' interoperability and related to data processing and the capabilities of the components in charge of information integration. Thus, interoperability mechanisms must be adopted [131] following IoT taxonomy, which approaches not only the Perception layer but all IoT layers [132].

This layer also embeds the fertigation trigger, which receives the fertigation command from the superior layers based on analyzed data.

Before reaching the superior layers, the data must be validated by a specific module that eliminates the observations, which significantly differ from the expected range of values due to, for example, intrinsic sensor errors [133]. In addition, the data validation module tries to detect the cause of the failure.

\subsubsection{Network Layer}

This layer comprises the network devices and data buses. In what concerns the communication technology, 4G, Wi-Fi, and LoRa technologies are the candidates, each suitable for a certain scenario. Thus, for image transmission, $4 \mathrm{G}$ technology is employed. When referring to the sensor's data transmission, four scenarios arise.

1. Short-range communication scenario (I). The sensors are close to the gateway/router, and fast or/and frequent data retrieval is desired. Consequently, Wi-Fi technology is used.

2. Short-range communication scenario (II). The sensors are close to the gateway/router, and no fast and frequent data retrieval is required. Thus, LoRa technology is used.

3. Long-range communication scenario (I). The sensors are placed far from the gateway (outside the Wi-Fi module's range), and fast retrieval is desired. Thus, drones act as a Wi-Fi flying ad-hoc network, forwarding the data from the sensors to the Wi-Fi router (as we emphasized in Figure 9).

4. Long-range communication scenario (II). The sensors are placed far from the gateway (outside the Wi-Fi module's range), and no fast or frequent retrieval is required. Thus, LoRa communication will ensure data transmission.

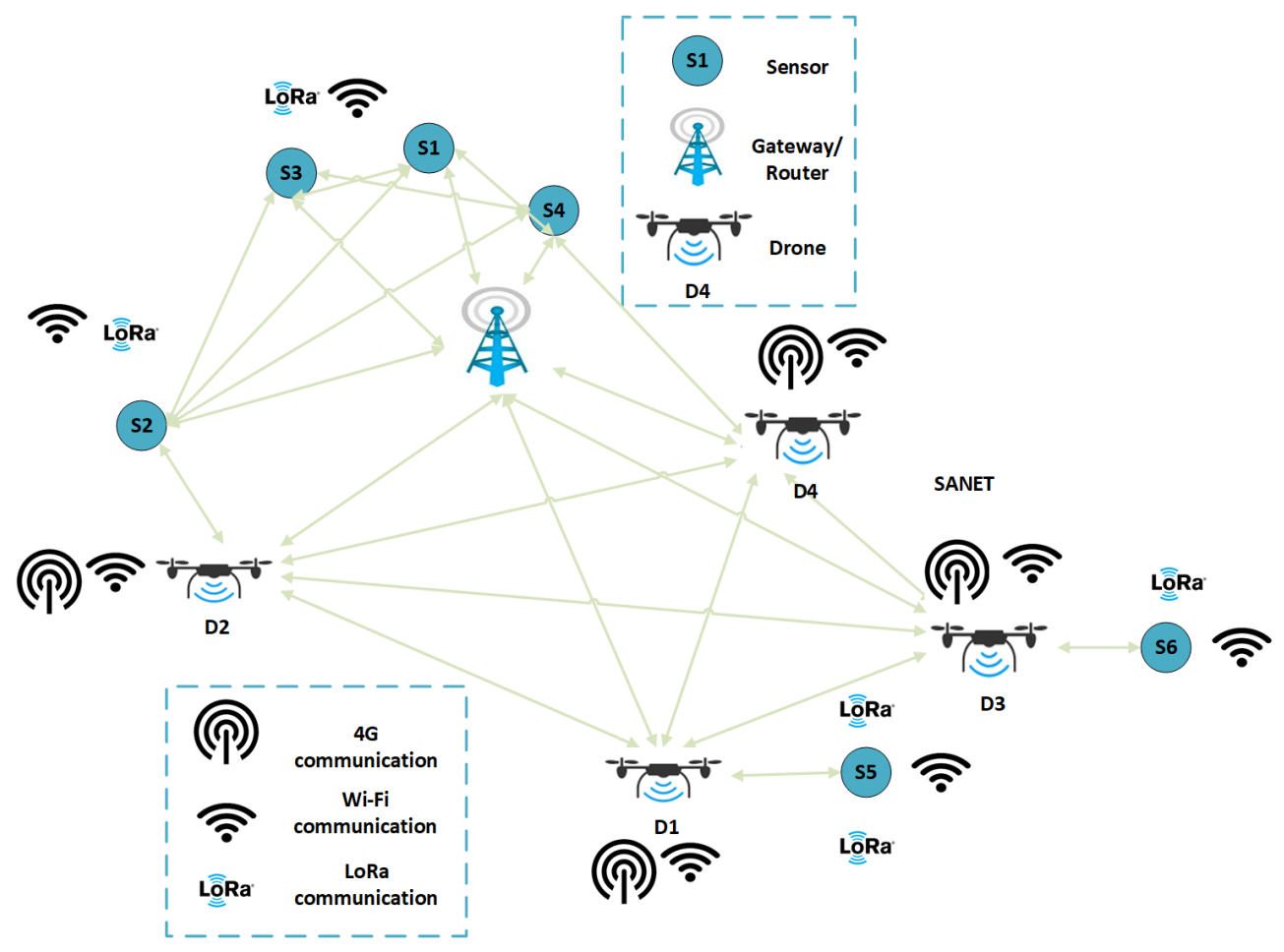

Figure 9. Scenarios for data communication. 
Using IoT-specific technologies and the real-time implementation of data buses, the sensors' data will be acquired in real-time.

\subsubsection{Cloud Layer}

The data are stored in Hadoop Distributed File System (HDFS) [134] repositories, successfully proven to outperform other approaches as those using a local file system [135]. HDSF will ensure the scalability of the system, allowing the application of distributed analysis techniques in large volumes of data, such as those supported by Spark or Map Reduce [136]. This analysis layer will allow the computer processing implementation through machine learning libraries such as those of Spark [137], which is also useful in determining cybersecurity issues.

The platform is not only composed of real-time messages provided by the previously mentioned channels but also unifies the analysis derived from satellite images and drones. This information requires the application of the necessary algorithm for the generation of new input variables to the global analysis process. The system ensures availability and scalability thanks to the distributed processing of the mentioned algorithms on the Hadoop architecture.

The platform oversees dividing the analysis works of large areas into smaller areas to adapt the computational load to each of the cluster nodes. This allows to subsequently address the technical complexities linked to resolving conflicts in the unification of the results.

Moreover, the blockchain component is in charge of transactions between farmers, the Amurg Tracer Tool, and other stakeholders (winemakers) to assure Amurg cultivar traceability. Amurg Tracer Tool is a component that integrates both data acquired from the field and quality-related data, which is input by the stakeholders.

\subsubsection{Application Layer}

The application layer comprises the application server where the applications are hosted [138]. Furthermore, at this layer, cybersecurity measures are implemented.

\subsection{Challenges}

The main technical challenges identified are the following:

- Integration of multiple data acquisition: Satellite imagery, UAVs have different resolutions, bands, and more important spectral responses. An image fusion technique is used with multisensor images to extract information of higher quality and reliability. However, there is not yet a unique model for an optimal workflow. The development of algorithms that will work consistently and independently of the satellite and with multiple data sources for exploitation is a remarkable challenge.

- Development and integration of smart algorithms: In the case of the UAVs, developing an algorithm able to transform images into spatial (efficiency from volume of grapes and bunch of grapes) and chemical information of the samples (quality end maturity parameters).

- To ensure a good prediction capability: Integration of Blockchain technology for data security.

\section{Conclusions, Future Directions and Open Challenges}

The paper introduces the actual challenges in viticulture as a foundation of winemaking due to climate change, as well as the most recent accomplishments of the IoT use in viticulture. With the improvement of vineyard productivity, farm profitability will be increased as well. At present, grapevine cropping is based on data manually collected in the field, which is a low-performance practice, as it is a discontinuous procedure that does not consider all the environmental factors imperceptible to human operators. On the other hand, manual collection may help to filter the unreliable data that may lead to incorrect presumptions. 
This paper proposes a novel technology, Climate Change-based Precision Viticulture, which fusions viticultural practices and experience, climate change influence, and IoTbased systems for precision viticulture. This technology aims at better environmental sustainability, addressing a new market featured by emerging technologies. By implementing the proposed IoT architecture, one will deliver a solution for smart viticulture, covering all phenological stages of Amurg grapes and the most relevant strategic and operational applications for vineyards: plant health, pesticide detection, resource efficiency, grape quality, and maturation.

The high volume of data sets, the increased number of data sources, and the energy demand for reliable communication impact the complexity of the process of data gathering. Consequently, using emerging technologies to gather viticultural data such as time-series data from IoT devices, spatial images from UAV-mounted multi-spectral cameras, or GPS and GIS-based mapping systems that collaborate to collect large environmental data sets will bring the added value to viticulture systems and will leverage the drawbacks of current practices. Moreover, using smart applications, the automatic procedures can be complemented by human observations and annotations. The benefits of the proposed concept and architecture can be extended in other regions and countries, as well as other agriculture domains, such that the labor tasks of the agriculture workers are reduced, and the resources are allocated in a more efficient manner. Further, increased data quality and processed data amounts provide many insights such that the productivity is enhanced whereas more sustainable and environmental-friendly processes are recognized and promoted.

The novel technology proposed in the framework of the viticultural practice in the Târnave vineyard, once the challenges are overcome, will open new perspectives for grapevine cultivation in this area. Enriching the wine assortment with a new, red, autochthonous, disease tolerant grape cultivar has been an aim of SCDVV Blaj since the Amurg cultivar was homologated in 1989. Developed for this region, it has not yet found good climatic ground for high grape productions. Thus, the actual climate warming conditions, together with the new technology presented, are an excellent foundation for Transylvanian vineyards to enlarge their wine assortment and production with new cultivars. This also opens up new marketing possibilities for these vineyards.

The future directions involve the practical application of the system in Târnave vineyards, a project that started this year. Along with the overall system development, the outcomes are shared with the region's farmers such that the benefits of this technology will ensure high grape and wine yields in the area's climate change context.

Our proposed system also aims to bring solutions that can be adapted to vineyards in other regions or countries as well. Thus, as open challenges, we have the extension of the system in Transylvania and beyond, and if the international specialists find our idea applicable, we would be more than happy to collaborate for it. Another challenge will be the assessment of the system as a tool for enlarging the grapevine cultivars and producing wine assortment for any other cultivar in any climatic conditions in any vineyard that will be intended for use.

Author Contributions: Conceptualization, V.S.C., A.-M.D. and C.B.; methodology, V.S.C., A.-M.D., L.L.T., M.L.I.; validation, V.S.C., A.-M.D., L.L.T., C.B., M.L.I.; investigation, V.S.C., A.-M.D., L.L.T., C.B., M.L.I.; resources, V.S.C., L.L.T., C.B., M.L.I.; writing-original draft preparation, V.S.C., A.M.D., L.L.T., C.B., M.L.I.; writing-review and editing, V.S.C., A.-M.D.; supervision, V.S.C.; funding acquisition, V.S.C., L.L.T. All authors have read and agreed to the published version of the manuscript.

Funding: This work was supported by the Romanian Ministry of Agriculture and Rural Development, grant numbers ADER 7.5.3 and ADER 7.1.4. and by a grant of the Romanian Ministry of Education and Research, CCCDI-UEFISCDI, project number PN-III-P2-2.1-PED-2019-1945, within PNCDI III.

Institutional Review Board Statement: Not applicable.

Informed Consent Statement: Not applicable. 
Data Availability Statement: The data presented in this study are available on request from the corresponding author.

Acknowledgments: The authors express their gratitude to George Suciu, Jr. and Ionel Zătreanu from Beia Consult International, Bucharest, Romania, for their support.

Conflicts of Interest: The authors declare no conflict of interest.

\section{References}

1. Tiefenbacher, J.P.; Townsend, C. The Semiofoodscape of Wine: The Changing Global Landscape of Wine Culture and the Language of Making, Selling, and Drinking Wine. In Handbook of the Changing World Language Map; Springer International Publishing: Basel, Switzerland, 2019; pp. 1-44. [CrossRef]

2. Mullins, M. Biology of the Grapevine; Cambridge University Press: Cambridge, NY, USA, 1992.

3. Gramaje, D.; Úrbez-Torres, J.R.; Sosnowski, M.R. Managing Grapevine Trunk Diseases with Respect to Etiology and Epidemiology: Current Strategies and Future Prospects. Plant Dis. 2018, 102, 12-39. [CrossRef] [PubMed]

4. Possingham, J. On the growing of grapevines in the tropics. Acta Hortic. 2004, 39-44. [CrossRef]

5. Jordão, A.; Vilela, A.; Cosme, F. From Sugar of Grape to Alcohol of Wine: Sensorial Impact of Alcohol in Wine. Beverages 2015, 1, 292-310. [CrossRef]

6. Guguchkina, T.; Antonenko, M.; Yakimenko, Y. New grape varieties for production of high-quality wines, and assessment methodology for varietal characteristics of the product. BIO Web Conf. 2020, 25, 02016. [CrossRef]

7. Santos, J.A.; Fraga, H.; Malheiro, A.C.; Moutinho-Pereira, J.; Dinis, L.T.; Correia, C.; Moriondo, M.; Leolini, L.; Dibari, C.; Costafreda-Aumedes, S.; et al. A Review of the Potential Climate Change Impacts and Adaptation Options for European Viticulture. Appl. Sci. 2020, 10, 3092. [CrossRef]

8. Gokcekus, O.; Fargnoli, A. Is Globalization Good for Wine Drinkers in the United States? J. Wine Econ. 2007, 2, 187-195. [CrossRef]

9. Anderson, K. Wine's Gradual Globalization. In Handbook of Eating and Drinking; Springer International Publishing: Basel, Switzerland, 2019; pp. 1-17. [CrossRef]

10. Leeuwen, C.V.; Seguin, G. The concept of terroir in viticulture. J. Wine Res. 2006, 17, 1-10. [CrossRef]

11. Vaudour, E. The Quality of Grapes and Wine in Relation to Geography: Notions of Terroir at Various Scales. J. Wine Res. 2002, 13, 117-141. [CrossRef]

12. Meinert, L.D. 8. WINE AND TERROIR. Geochem. Perspect. 2020, 9, 99-112.

13. Charters, S.; Spielmann, N.; Babin, B.J. The nature and value of terroir products. Eur. J. Mark. 2017, 51, 748-771. [CrossRef]

14. Schaller, K. Terroir-Myth and/or Reality-Outstanding Marketing Idea? A Review. Not. Bot. Horti Agrobot. Cluj-Napoca 2017, 45, 332-342. [CrossRef]

15. Clingeleffer, P. Terroir: The Application of an Old Concept in Modern Viticulture. In Encyclopedia of Agriculture and Food Systems; Elsevier: Amsterdam, The Netherlands, 2014; pp. 277-288. [CrossRef]

16. Belda, I.; Gobbi, A.; Ruiz, J.; de Celis, M.; Ortiz-Álvarez, R.; Acedo, A.; Santos, A. Microbiomics to Define Wine Terroir. In Comprehensive Foodomics; Elsevier: Amsterdam, The Netherlands, 2021; pp. 438-451. [CrossRef]

17. Reiss, M.; Bernard, B.; Jedicke, E. Climate Change Resilience in Viticulture: Knowledge transfer and ecosystem services of adaptation strategies. In Proceedings of the EGU General Assembly 2020, Vienna, Austria, 3-8 May 2020 ; p. 37.

18. Drumonde-Neves, J.; Franco-Duarte, R.; Lima, T.; Schuller, D.; Pais, C. Association between Grape Yeast Communities and the Vineyard Ecosystems. PLoS ONE 2017, 12, e0169883. [CrossRef] [PubMed]

19. Chiu, A.Y.T. The Effect of Region of Origin on the Individual Brands in the Region: A Study About São Roque and Vinícola Goés. Ph.D. Thesis, Escola de Administração de Empresas de São Paulo da Fundação Getulio Vargas, São Paulo, Brazil, 2020.

20. Feinberg, R. Uprooting wine. Food Cult. Soc. 2020, 23, 551-569. [CrossRef]

21. Rossi, A.; Cortassa, D. Exploring Italy's Wine Law Reforms. In Wine Law and Policy; Brill|Nijhoff: Leiden, The Netherlands, 2020; pp. 99-126. [CrossRef]

22. Charters, S.; Pettigrew, S. The dimensions of wine quality. Food Qual. Prefer. 2007, 18, 997-1007. [CrossRef]

23. Rahman, I.; Reynolds, D. Wine: Intrinsic attributes and consumers' drinking frequency, experience, and involvement. Int. J. Hosp. Manag. 2015, 44, 1-11. [CrossRef]

24. Chironi, S.; Altamore, L.; Columba, P.; Bacarella, S.; Ingrassia, M. Study of Wine Producers' Marketing Communication in Extreme Territories-Application of the AGIL Scheme to Wineries' Website Features. Agronomy 2020, 10, 721. [CrossRef]

25. Lemaire, D.; Kasserman, D. Bordeaux and Burgundy: A Comparison of Two French Wine Regions in Transition. In The Geography of Wine; Springer: Cham, The Netherlands, 2011; pp. 61-80. [CrossRef]

26. Niemeyer, K. A theoretical approach to vintage: From oenology to media. NECSUS Eur. J. Media Stud. 2015, 4, 85-102. [CrossRef]

27. Faye, B.; Fur, E.L.; Prat, S. Dynamics of fine wine and asset prices: Evidence from short- and long-run co-movements. Appl. Econ. 2015, 47, 3059-3077. [CrossRef]

28. Geană, E.I.; Ciucure, C.T.; Apetrei, C.; Artem, V. Application of Spectroscopic UV-Vis and FT-IR Screening Techniques Coupled with Multivariate Statistical Analysis for Red Wine Authentication: Varietal and Vintage Year Discrimination. Molecules 2019, 24, 4166. [CrossRef] 
29. van Leeuwen, C.; Destrac-Irvine, A.; Dubernet, M.; Duchêne, E.; Gowdy, M.; Marguerit, E.; Pieri, P.; Parker, A.; de Rességuier, L.; Ollat, N. An Update on the Impact of Climate Change in Viticulture and Potential Adaptations. Agronomy 2019, 9, 514. [CrossRef]

30. Hall, C.M.; Mitchell, R. Wine Marketing; Routledge: London, UK, 2007. [CrossRef]

31. Fraga, H. Viticulture and Winemaking under Climate Change. Agronomy 2019, 9, 783. [CrossRef]

32. Sillmann, J.; Thorarinsdottir, T.; Keenlyside, N.; Schaller, N.; Alexander, L.V.; Hegerl, G.; Seneviratne, S.I.; Vautard, R.; Zhang, X.; Zwiers, F.W. Understanding, modeling and predicting weather and climate extremes: Challenges and opportunities. Weather Clim. Extrem. 2017, 18, 65-74. [CrossRef]

33. Cyr, D.; Kusy, M.; Shaw, A.B. Climate Change and the Potential Use of Weather Derivatives to Hedge Vineyard Harvest Rainfall Risk in the Niagara Region. J. Wine Res. 2010, 21, 207-227. [CrossRef]

34. Webb, L.; Whiting, J.; Watt, A.; Hill, T.; Wigg, F.; Dunn, G.; Needs, S.; Barlow, E.W. Managing Grapevines through Severe Heat: A Survey of Growers after the 2009 Summer Heatwave in South-eastern Australia. J. Wine Res. 2010, 21, 147-165. [CrossRef]

35. Jones, G.V.; Webb, L.B. Climate Change, Viticulture, and Wine: Challenges and Opportunities. J. Wine Res. 2010, $21,103-106$. [CrossRef]

36. Jones, G.V.; White, M.A.; Cooper, O.R.; Storchmann, K. Climate Change and Global Wine Quality. Clim. Chang. 2005, 73, 319-343. [CrossRef]

37. Hadarits, M.; Smit, B.; Diaz, H. Adaptation in Viticulture: A Case Study of Producers in the Maule Region of Chile. J. Wine Res. 2010, 21, 167-178. [CrossRef]

38. Schultz, H.R.; Jones, G.V. Climate Induced Historic and Future Changes in Viticulture. J. Wine Res. 2010, 21, 137-145. [CrossRef]

39. Jones, G.V.; Reid, R.; Vilks, A. Climate, Grapes, and Wine: Structure and Suitability in a Variable and Changing Climate. In The Geography of Wine; Springer: Cham, The Netherlands, 2011; pp. 109-133. [CrossRef]

40. Hannah, L.; Roehrdanz, P.R.; Ikegami, M.; Shepard, A.V.; Shaw, M.R.; Tabor, G.; Zhi, L.; Marquet, P.A.; Hijmans, R.J. Climate change, wine, and conservation. Proc. Natl. Acad. Sci. USA 2013, 110, 6907-6912. [CrossRef] [PubMed]

41. Cogato, A.; Meggio, F.; De Antoni Migliorati, M.; Marinello, F. Extreme Weather Events in Agriculture: A Systematic Review. Sustainability 2019, 11, 2547. [CrossRef]

42. Van Loon, J.; Speratti, A.B.; Gabarra, L.; Govaerts, B. Precision for Smallholder Farmers: A Small-Scale-Tailored Variable Rate Fertilizer Application Kit. Agriculture 2018, 8, 48. [CrossRef]

43. Wen, S.; Zhang, Q.; Deng, J.; Lan, Y.; Yin, X.; Shan, J. Design and Experiment of a Variable Spray System for Unmanned Aerial Vehicles Based on PID and PWM Control. Appl. Sci. 2018, 8, 2482. [CrossRef]

44. Van der Merwe, D.; Burchfield, D.R.; Witt, T.D.; Price, K.P.; Sharda, A. Drones in agriculture. In Advances in Agronomy; Elsevier: Amsterdam, The Netherlands, 2020; pp. 1-30. [CrossRef]

45. de Castro, A.I.; Peña, J.M.; Torres-Sánchez, J.; Jiménez-Brenes, F.M.; Valencia-Gredilla, F.; Recasens, J.; López-Granados, F. Mapping Cynodon Dactylon Infesting Cover Crops with an Automatic Decision Tree-OBIA Procedure and UAV Imagery for Precision Viticulture. Remote Sens. 2020, 12, 56. [CrossRef]

46. Tropea, M.; Santamaria, A.F.; Potrino, G.; Rango, F.D. Bio-Inspired Recruiting Protocol for FANET in Precision Agriculture Domains: Pheromone Parameters Tuning. In Proceedings of the 2019 Wireless Days (WD), Manchester, UK, 24-26 April 2019; pp. 1-6. [CrossRef]

47. Isaac, W.A.P.; Ganpat, W.G.; Bridgemohan, P.; Attzs, M. Defining a Policy Nexus for Sustainable Agriculture and Food Security in the Caribbean Region. In Global Climate Change: Resilient and Smart Agriculture; Springer: Singapore, 2020; pp. 1-13. [CrossRef]

48. Roy, T.; George K, J. Precision Farming: A Step Towards Sustainable, Climate-Smart Agriculture. In Global Climate Change: Resilient and Smart Agriculture; Springer: Singapore, 2020; pp. 199-220. [CrossRef]

49. Pérez-Expósito, J.P.; Fernández-Caramés, T.M.; Fraga-Lamas, P.; Castedo, L. An IoT Monitoring System for Precision Viticulture. In Proceedings of the 2017 IEEE International Conference on Internet of Things (iThings) and IEEE Green Computing and Communications (GreenCom) and IEEE Cyber, Physical and Social Computing (CPSCom) and IEEE Smart Data (SmartData), Exeter, UK, 21-23 June 2017; pp. 662-669. [CrossRef]

50. Caprio, E.; Nervo, B.; Isaia, M.; Allegro, G.; Rolando, A. Organic versus conventional systems in viticulture: Comparative effects on spiders and carabids in vineyards and adjacent forests. Agric. Syst. 2015, 136, 61-69. [CrossRef]

51. Likar, M.; Stres, B.; Rusjan, D.; Potisek, M.; Regvar, M. Ecological and conventional viticulture gives rise to distinct fungal and bacterial microbial communities in vineyard soils. Appl. Soil Ecol. 2017, 113, 86-95. [CrossRef]

52. Hendgen, M.; Döring, J.; Stöhrer, V.; Schulze, F.; Lehnart, R.; Kauer, R. Spatial Differentiation of Physical and Chemical Soil Parameters under Integrated, Organic, and Biodynamic Viticulture. Plants 2020, 9, 1361. [CrossRef]

53. Maykish, A.; Rex, R.; Sikalidis, A.K. Organic Winemaking and Its Subsets; Biodynamic, Natural, and Clean Wine in California. Foods 2021, 10, 127. [CrossRef]

54. Commision, E. Integrated Pest Management (IPM). Available online: https://ec.europa.eu/food/plant/pesticides/sustainable_ use_pesticides/ipm_en (accessed on 12 February 2021).

55. Jose, M.L. Long Island Sustainable Winegrowing: The Road to Certification, 3rd ed.; Rivers Run By Press: Ardsley, NY, USA, 2019.

56. Biological, I.O.; Control, I. Integrated Production Objectives and Principles. Available online: https://www.iobc-wprs.org/ (accessed on 16 February 2021).

57. Karlsson, B. Organic, Biodynamic and Sustainable Wine, an Overview. 2020. Available online: https://www.bkwine.com/ features/winemaking-viticulture/organic-biodynamic-sustainable-wine-overview-part-1/ (accessed on 16 February 2021). 
58. Cordero-Bueso, G.; Arroyo, T.; Valero, E. A long term field study of the effect of fungicides penconazole and sulfur on yeasts in the vineyard. Int. J. Food Microbiol. 2014, 189, 189-194. [CrossRef] [PubMed]

59. Mackie, K.; Müller, T.; Kandeler, E. Remediation of copper in vineyards-A mini review. Environ. Pollut. 2012, 167, 16-26. [CrossRef] [PubMed]

60. Meissner, G.; Athmann, M.E.; Fritz, J.; Kauer, R.; Stoll, M.; Schultz, H.R. Conversion to organic and biodynamic viticultural practices: Impact on soil, grapevine development and grape quality. OENO ONE 2019, 53. [CrossRef]

61. Zanzotti, R.; Mescalchin, E. Green manure effects on inorganic nitrogen dynamics in soil and its accumulation in grape must. BIO Web Conf. 2019, 13, 04010. [CrossRef]

62. Litskas, V.; Mandoulaki, A.; Vogiatzakis, I.N.; Tzortzakis, N.; Stavrinides, M. Sustainable Viticulture: First Determination of the Environmental Footprint of Grapes. Sustainability 2020, 12, 8812. [CrossRef]

63. Tomoiagă, L.L.; Ficiu, L.; Tabaranu, G.; Argatu, C.; Zaldea, G.; Vizitiu, D. Studies on Biodiversity Diagnosis of Vineyard Farms at the Agro-Ecological Infrastructure Level. Bull. Univ. Agric. Sci. Vet. Med. Cluj-Napoca Hortic. 2016, 73, 205. [CrossRef]

64. Spachos, P.; Gregori, S. Integration of Wireless Sensor Networks and Smart UAVs for Precision Viticulture. IEEE Internet Comput. 2019, 23, 8-16. [CrossRef]

65. Döring, J.; Collins, C.; Frisch, M.; Kauer, R. Organic and Biodynamic Viticulture Affect Biodiversity and Properties of Vine and Wine: A Systematic Quantitative Review. Am. J. Enol. Vitic. 2019, 70, 221-242. [CrossRef]

66. Döring, J.; Frisch, M.; Tittmann, S.; Stoll, M.; Kauer, R. Growth, Yield and Fruit Quality of Grapevines under Organic and Biodynamic Management. PLoS ONE 2015, 10, e0138445. [CrossRef]

67. Leiber, F.; Fuchs, N.; Spiess, H. Biodynamic Agriculture today. In Organic Agriculture: A Global Perspective; CABI: Wallingford, UK, 2006; pp. 141-149. [CrossRef]

68. Masson, P. Landwirtschaft, Garten- und Weinbau Biodynamisch; AT-Verl: Verl, Germany, 2013.

69. Setati, M.E.; Jacobson, D.; Andong, U.C.; Bauer, F. The vineyard yeast microbiome, a mixed model microbial map. PLoS ONE 2012, 7, e52609. [CrossRef]

70. Coller, E.; Cestaro, A.; Zanzotti, R.; Bertoldi, D.; Pindo, M.; Larger, S.; Albanese, D.; Mescalchin, E.; Donati, C. Microbiome of vineyard soils is shaped by geography and management. Microbiome 2019, 7. [CrossRef] [PubMed]

71. Spachos, P. Towards a Low-Cost Precision Viticulture System Using Internet of Things Devices. IoT 2020, 1, 5-20. [CrossRef]

72. Ammoniaci, M.; Kartsiotis, S.P.; Perria, R.; Storchi, P. State of the Art of Monitoring Technologies and Data Processing for Precision Viticulture. Agriculture 2021, 11, 201. [CrossRef]

73. Pedersen, S.; Pedersen, M.; Ørum, J.; Fountas, S.; Balafoutis, A.; van Evert, F.; van Egmond, F.; Knierim, A.; Kernecker, M.; Mouazen, A. Economic, environmental and social impacts. In Agricultural Internet of Things and Decision Support for Precision Smart Farming; Elsevier: Amsterdam, The Netherlands, 2020; pp. 279-330. [CrossRef]

74. Bălăceanu, C.; Negoiţă, A.; Drăgulinescu, A.M.; Roşcăneanu, R.; Chedea, V.S.; Suciu, G., Jr. The use of IoT technology in Smart Viticulture. In Proceedings of the 23rd Conference on Control Systems and Computer Science, Intelligence, Systems and Applications (IISA), Online, 12-14 July 2021; pp. 362-369. [CrossRef]

75. Libelium. Libelium Smart Agriculture Xtreme IoT Vertical Kit. 2020. Available online: https://www.the-iot-marketplace.com/ libelium-smart-agriculture-xtreme-iot-vertical-kit (accessed on 10 June 2021).

76. Maraš, V.; Popović, T.; Gajinov, S.; Mugoša, M.; Popović, V.; Savović, A.; Pavićević, K.; Mirović, V. Precision Viticulture Using Wireless Sensor Network. In Proceedings of the 2020 9th Mediterranean Conference on Embedded Computing (MECO), Budva, Montenegro, 8-11 June 2020; pp. 1-6. [CrossRef]

77. Mouakher, A.; Belkaroui, R.; Bertaux, A.; Labbani, O.; Hugol-Gential, C.; Nicolle, C. An Ontology-Based Monitoring System in Vineyards of the Burgundy Region. In Proceedings of the 2019 IEEE 28th International Conference on Enabling Technologies: Infrastructure for Collaborative Enterprises (WETICE), Naples, Italy, 12-14 June 2019; pp. 307-312. [CrossRef]

78. Oliver, S.T.; González-Pérez, A.; Guijarro, J.H. An IoT Proposal for Monitoring Vineyards Called SEnviro for Agriculture. In Proceedings of the 8th International Conference on the Internet of Things-IOT'18, Santa Barbara, CA, USA, 15-18 October 2018; Association for Computing Machinery: New York, NY, USA, 2018. [CrossRef]

79. Pepper, I.; Brusseau, M. Chapter 2-Physical-Chemical Characteristics of Soils and the Subsurface. In Environmental and Pollution Science, 3rd ed.; Brusseau, M.L., Pepper, I.L., Gerba, C.P., Eds.; Academic Press: Cambridge, MA, USA, 2019; pp. 9-22. [CrossRef]

80. Voutos, Y.; Mylonas, P.; Spyrou, E.; Charou, E. An IoT-Based Insular Monitoring Architecture for Smart Viticulture. In Proceedings of the 2018 9th International Conference on Information, Intelligence, Systems and Applications (IISA), Zakynthos, Greece, 23-25 July 2018; pp. 1-4. [CrossRef]

81. João, L.; Machado, R.; Tabim, V.; Cardoso, A.; Lopes, J.L.; Pernas, A.; Yamin, A. Applying the Internet of Things in Precision Viticulture: An Approach Exploring the EXEHDA Middleware. In Proceedings of the 2018 XLIV Latin American Computer Conference (CLEI), São Paulo, Brazil, 1-5 October 2018; pp. 680-687. [CrossRef]

82. Giordano, S.; Verrastro, V. IoT technologies in viticulture: Innovation and Sustainability. The IoF Project case study. GeoProgress J. 2020, 7, 57-71.

83. Suciu, G.; Fratu, O.; Vulpe, A.; Butca, C.; Suciu, V. IoT agro-meteorology for viticulture disease warning. In Proceedings of the 2016 IEEE International Black Sea Conference on Communications and Networking (BlackSeaCom), Varna, Bulgaria, 6-9 June 2016; pp. 1-5. [CrossRef] 
84. Suciu, G.; Vulpe, A.; Fratu, O.; Suciu, V. M2M remote telemetry and cloud IoT big data processing in viticulture. In Proceedings of the 2015 International Wireless Communications and Mobile Computing Conference (IWCMC), Dubrovnik, Croatia, 24-28 August 2015; pp. 1117-1121. [CrossRef]

85. Orozco-Barbosa, L.; García, F.M.; Ramos, A.B.; Riquelme, F.M. An Experimental Evaluation of IoT Technologies in Precision Viticulture. In Lecture Notes of the Institute for Computer Sciences, Social Informatics and Telecommunications Engineering; Springer International Publishing: Basel, Switzerland, 2016; pp. 51-62. [CrossRef]

86. Trilles, S.; Torres-Sospedra, J.; Belmonte, Ó.; Zarazaga-Soria, F.J.; González-Pérez, A.; Huerta, J. Development of an open sensorized platform in a smart agriculture context: A vineyard support system for monitoring mildew disease. Sustain. Comput. Inform. Syst. 2020, 28, 100309. [CrossRef]

87. FAOSTAT. 2021 Food and Agriculture Organization of the United Nations. Available online: www.fao.org/faostat/en/\#data/QC (accessed on 12 April 2021).

88. FAOSTAT. 2021 Food and Agriculture Organization of the United Nations. Available online: www.fao.org/faostat/en/\#data/QD (accessed on 12 April 2021).

89. Organisation Internationale Vitivinicole Note de Conjoncture Vitivinicole Mondiale 2020. 2020. Available online: https: //www.oiv.int/public/medias/7899/oiv-note-de-conjoncture-vitivinicole-mondiale-2020.pdf (accessed on 2 July 2021).

90. Kottek, M.; Grieser, J.; Beck, C.; Rudolf, B.; Rubel, F. World Map of the Köppen-Geiger climate classification updated. Meteorol. Z. 2006, 15, 259-263. [CrossRef]

91. Irimia, L.M.; Patriche, C.V.; Roșca, B. Climate change impact on climate suitability for wine production in Romania. Theor. Appl. Climatol. 2017, 133, 1-14. [CrossRef]

92. Dumitrescu, A.; Bojariu, R.; Birsan, M.V.; Marin, L.; Manea, A. Recent climatic changes in Romania from observational data (1961-2013). Theor. Appl. Climatol. 2014, 122, 111-119. [CrossRef]

93. Bălteanu, D.; Chendeş, V.; Sima, M.; Enciu, P. A country-wide spatial assessment of landslide susceptibility in Romania. Geomorphology 2010, 124, 102-112. [CrossRef]

94. Chirciu, I.A.; Zaharia, I.; Soare, E. Production Of Wine Grapes And Cultural Traditions Related To Vine In Romania. Sci. Pap. Ser. Manag. Econ. Eng. Agric. Rural Dev. 2020, 20, 133-144. [CrossRef]

95. Cichi, D.D.; Stoica, F.; Muntean, C.; Cichi, M.; Cîmpeanu, C.B. Table Grapes Production Sector In Romania-Evaluation, The Current State And Perspectives. Sci. Pap. Ser. Hortic. 2019, 63, 217-226.

96. Romania Map. Available online: https://www.mapsofworld.com/romania/ (accessed on 7 March 2021).

97. Rotaru, L.; Colibaba, L.C.; Aelenei, S.I. The agrobiological and technological value of ancient Romanian grape varieties cultivated in Iaşi vineyard. Lucr. Ştiinţifice, Univ. Ştiinţe Agric. Med. Vet. Ion Ionescu Brad Iaşi Ser. Hortic. 2018, 61, 135-138.

98. Tomoiagă, L.L.; Chedea, V.S. Grapevine Trunk Diseases Management in Vineyards from Central Transylvania. Bull. Univ. Agric. Sci. Vet. Med. Cluj-Napoca Hortic. 2020, 77, 117. [CrossRef]

99. Iliescu, M.; Tomoiaga, L.; Chedea, V.S.; Pop, E.A.; Sirbu, A.; Popa, M.; Calugar, A.; Babes, A. Evaluation Of Climate Changes On The Vine Agrosystem In Tarnave Vineyard. J. Environ. Prot. Ecol. 2019, 20, 1754-1760.

100. Oşlobeanu, M. Zonarea Soiurilor de viţă de vie în România; Ceres: Bucharest, Romania, 1991.

101. Iliescu, M.; Tomoiaga, L.; Farago, M.; Comsa, M. The Nutrition of Vine in Tarnave; Academic Press: Cambridge, MA, USA, 2010.

102. Cudur, F.; Iliescu, M.; Comsa, M.; Popescu, D.; Cristea, C. Soil Type Influence On Yield Quantity And Quality At Grape Varieties for White Wines Obtained In The Viticultural Centre Blaj. Bull. Univ. Agric. Sci. Vet. Med. Cluj-Napoca Hortic. 2014, 71, 21-28.

103. Călugăr, A.; Babeş, A.C.; Bunea, C.I.; Pop, T.I.; Tomoiagă, L.; Iliescu, M. Oenological characterization of wines from grape clones created at Research Station for Viticulture and Enology Blaj, Romania. Stiinta Agric. 2018, 2018, 50-56.

104. Donici, A.; Bunea, C.I.; Călugăr, A.; Harsan, E.; Bora, F.D. Investigation of the copper content in vineyard soil, grape, must and wine in the main vineyards of Romania: A preliminary study. Bull. UASVM Hortic 2019, 76, 31-46. [CrossRef]

105. Valeriu, C. Podgoriile şi Vinurile României; Ed. Acad. Române: Bucurest, Romania, 2003.

106. Coros, M.M.; Pop, A.M.; Popa, A.I. Vineyards and Wineries in Alba County, Romania towards Sustainable Business Development. Sustainability 2019, 11, 4036. [CrossRef]

107. Macici, M. Romania's Wines; Alcor Edimpex SRL: Bucharest, Romania, 1996.

108. SCDVV. Brief History of SCDVV Blaj. 2021. Available online: https://www.scvblaj.ro/articole/scurt-istoric-al-scdvv-blaj (accessed on 28 January 2021).

109. Popescu, D.; Iliescu, M.; Cristea, C.; Comşa, M. Researches Regarding the Agrotehnic Behaviour of Perspective Elites Obtained at Research Station for Viticulture and Enology Blaj. Bull. Univ. Agric. Sci. Vet. Med. Cluj-Napoca Hortic. 2014, 71, 293-298. [CrossRef]

110. Stroe, M. Ampelografie; Ceres Publishing House: Bucharest, Romania, 2012.

111. Comșa, A.; Cristea, C.; Cudur, F. Behaviour In The Production Of New Varieties For White Wines Created at SCDVV Blaj. In Proceedings of the Simpozionul Ştiinţific Anual Cu Participare Internaţională “Horticultura—Ştiinţă, Calitate, Diversitate Şi Armonie", Iași, Romania, 26-28 May 2011

112. Comșa, A.; Cristea, C.; Cudur, F. Perspective clone elites from the Italian Riesling variety, Scientifical papers. USAMV Bucur. Ser. Hortic. 2011, LV, 501-504.

113. Iliescu, M.; Tomoiagă, L.; Babeș, A.C.; Călugăr, A. New Grapevine Variety Created And Approved: Roze Blaj. In Proceedings of the 2020 19th International Conference Life Sciences for Sustainable Development, Cluj-Napoca, Romania, 25 September 2020. 
114. Sîrbu, A.; Tomoiagă, L.; Vasiu, I.; Chedea, V.S.; Iliescu, M. New Wines from Târnave vineyard: SELENA and Blasius. In Proceedings of the 2020 19th International Conference Life Sciences for Sustainable Development, Cluj-Napoca, Romania, 25 Sptember 2020.

115. Iliescu, M.; Tomoiagă, L.; Elena, A.P.; Sîrbu, A. Soiuri noi de struguri, create la SCDVV Blaj SELENA—Soi pentru vinuri albe, DOC BLASIUS-Soi recomandat pentru vinuri albe de calitate superioara. InfoAMSEM J. 2020, 3, 20

116. Iliescu, M.; Tomoiagă, L.; Bărbuleţiu, A.; Pop, A.; Sîrbu, A.; Şerbu, F. Clona de viţă de vie pentru vinuri albe Pinot Gris 11BL. In Oferta Cercetării; ASAS: București, Romania, 2020.

117. Tomoiagă, L.L.; Iliescu, M.L.; Răcoare, H.S.; Botea, V.; Sîrbu, A.D.; Puşcă, G.; Chedea, V.S. Grape pomance generation from grape cultivars cultivated in Târnave vineyards in the framework of the climate change. Rom. J. Hortic. 2020, 1, 81-88. [CrossRef]

118. Pop, E.A.; Tomoiaga, L.; Victoria Artem, A.R.; Iliescu, M. Studies about climate change in the Târnave and Murfatlar Vineyards. Agricultura 2020, 113. [CrossRef]

119. Iliescu, M.L.; Tomoiagă, L.L.; Popa, E.A.; Sîrbu, A.D.; Botea, V.; Călugar, A.; Babeş, A.C.; Chedea, V.S. Potential effects of climate change on vine phenology and grape ripening in Târnave vineyard. In Proceedings of the 8th World Sustainability Forum, Geneva, Switzerland, 14-19 September 2020.

120. Comșa, A.; Cristea, C.; Cudur, F. Soiul de viţă de vie pentru vinuri roşii Amurg. In Oferta Cercetării; ASAS: Champaign, IL, USA, 2011.

121. Chedea, V.S.; Bălăceanu, C.M.; Tomoiagă, L.L.; Zătreanu, I.; Iliescu, M.L. Climate change-the ground for improving the cultivated assortment of grapevine varieties with new autochthonous disease tolerant grapevine varieties. In Proceedings of the 8th World Sustainability Forum, Geneva, Switzerland, 14-19 September 2020.

122. Janex-Favre, M.; Parguey-Leduc, A.; Jailloux, F. The ontogeny of pycnidia of Guignardia bidwellii in culture. Mycol. Res. 1993, 97, 1333-1339. [CrossRef]

123. Tomoiaga, L.; Criveanu, H.; Micle, S. Monitoring of climatic parameters an effective solution of fighting against the black rot of the vine (Black-Rot). In Proceedings of the UTC-N Symposium Modern Science and Energy, Cluj-Napoca, Romania, 15-17 May 2002; pp. 337-341.

124. Tomoiaga, L.; Chedea, V.S. The Behaviour of Some Grapevine Varieties to the Guignardia bidwellii Fungus Attack. Bull. Univ. Agric. Sci. Vet. Med. Cluj-Napoca Hortic. 2020, 77, 122. [CrossRef]

125. Tomoiaga, L.; Comsa, M. The strategy of optimization for combat the Black Rot of vine (Guignardia bidwellii), in the ecoclimatic conditions from vineyard Tarnave. Bull. Univ. Agric. Sci. Vet. Med. Cluj-Napoca Hortic. 2010, 67, 500.

126. Alves, A.; Phillips, A.J.; Henriques, I.; Correia, A. Rapid differentiation of species of Botryosphaeriaceae by PCR fingerprinting. Res. Microbiol. 2007, 158, 112-121. [CrossRef] [PubMed]

127. Wilcox, W.F. Black Rot Guignardia Bidwellii (Ellis) Viala and Ravaz; Disease Identification Sheet No. 102GFSG-D4; Cornell Cooperative: Ithaca, NY, USA, 2003.

128. Shi, X.; An, X.; Zhao, Q.; Liu, H.; Xia, L.; Sun, X.; Guo, Y. State-of-the-Art Internet of Things in Protected Agriculture. Sensors 2019, 19, 1833. [CrossRef]

129. Villa-Henriksen, A.; Edwards, G.T.; Pesonen, L.A.; Green, O.; Sørensen, C.A.G. Internet of Things in arable farming: Implementation, applications, challenges and potential. Biosyst. Eng. 2020, 191, 60-84. [CrossRef]

130. Tan, J.Y.; Ker, P.J.; Lau, K.Y.; Hannan, M.A.; Tang, S.G.H. Applications of Photonics in Agriculture Sector: A Review. Molecules 2019, 24, 2025. [CrossRef] [PubMed]

131. López-Morales, J.A.; Martínez, J.A.; Skarmeta, A.F. Digital Transformation of Agriculture through the Use of an Interoperable Platform. Sensors 2020, 20, 1153. [CrossRef] [PubMed]

132. Noura, M.; Atiquzzaman, M.; Gaedke, M. Interoperability in Internet of Things: Taxonomies and Open Challenges. Mob. Netw. Appl. 2018, 24, 796-809. [CrossRef]

133. Gaddam, A.; Wilkin, T.; Angelova, M.; Gaddam, J. Detecting Sensor Faults, Anomalies and Outliers in the Internet of Things: A Survey on the Challenges and Solutions. Electronics 2020, 9, 511. [CrossRef]

134. Ouafiq, E.M.; Elrharras, A.; Mehdary, A.; Chehri, A.; Saadane, R.; Wahbi, M. IoT in Smart Farming Analytics, Big Data Based Architecture. In Human Centred Intelligent Systems; Springer: Singapore, 2020; pp. 269-279. [CrossRef]

135. Xu, C.; Du, X.; Yan, Z.; Fan, X. ScienceEarth: A Big Data Platform for Remote Sensing Data Processing. Remote Sens. 2020, $12,607$. [CrossRef]

136. Diaconita, V.; Bologa, A.R.; Bologa, R. Hadoop Oriented Smart Cities Architecture. Sensors 2018, 18, 1181. [CrossRef]

137. Morfino, V.; Rampone, S. Towards Near-Real-Time Intrusion Detection for IoT Devices using Supervised Learning and Apache Spark. Electronics 2020, 9, 444. [CrossRef]

138. Colizzi, L.; Caivano, D.; Ardito, C.; Desolda, G.; Castrignanò, A.; Matera, M.; Khosla, R.; Moshou, D.; Hou, K.M.; Pinet, F.; et al. Chapter 1-Introduction to agricultural IoT. In Agricultural Internet of Things and Decision Support for Precision Smart Farming; Castrignanò, A., Buttafuoco, G., Khosla, R., Mouazen, A.M., Moshou, D., Naud, O., Eds.; Academic Press: Cambridge, MA, USA, 2020; pp. 1-33. [CrossRef] 